\title{
Fuzzy Logic and Sliding-Mode Speed Control Based Direct Torque and Flux Control Scheme to Improve the Performance of an Induction Motor Drive
}

\author{
Tejavathu Ramesh, Anup Kumar Panda, and S. Shiva Kumar \\ Dept. of Electrical Engineering, National Institute of Technology Rourkela, India \\ tramesh.ee@gmail.com, akpanda.ee@gmail.com
}

\begin{abstract}
In this research study, the performance of direct torque and flux control (DTFC) induction motor drive (IMD) is presented using four different speed control techniques. The performance of IMD mainly depends on the design of speed controller. The PI speed controller (PISC) requires precise mathematical model, continuous and appropriate gain values. Therefore, adaptive control based speed controller is desirable to achieve high performance drive. The sliding-mode speed controller (SMSC) is developed to achieve continuous control of motor speed and torque. Furthermore, the fuzzy logic speed controller (FLSC) and fuzzy sliding-mode speed controller (FSMSC) is designed to obtain high performance, dynamic tracking behavior, speed accuracy and also robustness to parameter variations. The performance of each control technique has been tested for its robustness to parameter uncertainties and load disturbances. The detailed comparison of different control schemes are carried out in a MATALB/Simulink environment at different speed operating conditions, such as, forward and reversal motoring under no-load, load and sudden change in speed.
\end{abstract}

Keywords: Direct torque control, induction motor drive, fuzzy logic speed controller, sliding mode speed controller, fuzzy sliding mode speed controller.

\section{Introduction}

In recent times, the adjustable speed drives (ASDs) with induction motor drives (IMDs) are making significant inroads because of robustness, high performance, and rugged structure and widely used in industrial applications such as; electric and hybrid vehicles, traction locomotives, electric propulsion ships The scalar control schemes are simple to implement and gives good steady state response, but poor in dynamic response. However, the vector control method gives good steady state as well as transient response [1]. In the vector control scheme, one of the most popular control method of induction motor drive is known as field oriented control (FOC). It controls an induction motor drive like a separately excited DC motor and it was proposed by F. Blaschke (Direct FOC) and Hasse (Indirect FOC) in early 1970's [2].

The FOC method has an attractive features but it suffers with some drawbacks, such as; requirement of co-ordinate transformations, current controllers, sensitive to parameter variations. The drawbacks of FOC schemes are minimized with the new control strategy i.e., direct torque control (DTC) scheme, which is proposed by Isao Takahashi and Toshihiko Noguchi, in the mid 1980's [3].

The performance of IMD mainly depends on the design of speed controller. The PISC is widely used in industrial applications as it has a simple structure and offers a good satisfactory performance over a wide range of normal operation. But, the PISC scheme may not give satisfactory performance under load disturbances and it requires precise mathematical model, continuous tuning and accurate gain values of proportional $(\mathrm{Kp})$ and integral $\left(\mathrm{K}_{\mathrm{I}}\right)$ to achieve high performance drive. It is quite difficult to gain high performance of an IMD using PISC, because of the nonlinear model of IMD. For example, if any sudden or unexpected change in motor speed or load disturbance occurs, that results to an undesired overshoot in motor speed,

Received: May $20^{\text {th }}, 2013$. Accepted: February $26^{\text {th }}, 2014$ 
long settling time, high stator flux and torque ripples. In the literature survey, lots of control strategies has been proposed to tune the gain values of PISC, like Ziegler-Nichols, root locus, pole assignment design and etc [4]. Therefore, on-line tuning based speed controller is in demand to get high performance drive. To overcome the above mentioned drawbacks and improve the system performance, adaptive control based speed controllers are required, such as self tuning PISC, SMC, artificial intelligent based controllers like FLSC, neural networks, neuro-fuzzy, genetic algorithms (GA) [5-11].

The SMSC is a nonlinear, high switching speed and feedback control strategy, which offers an effective and robust control for motor drive. The sliding mode control scheme has been proposed in [12] for stator flux oriented control and also for the vector control IM drives in [13-16].

The fuzzy logic controller (FLC) is a nonlinear control, it is robust to parameter variations in IMD and it does not requires precise mathematical models, it is based on human knowledge. The author of [17] has proposed a SMSC and FLSC for vector control of induction motor drive, a new hybrid fuzzy logic controller has been presented in [18].

This paper presents a comparative study between four different speed controller techniques. The SMSC scheme is implemented to improve the dynamic response and also minimize the ripple contents of stator flux and torque, it is derived based on Lyapunov theory. Furthermore, the FLSC and FSMSC schemes are implemented to enhance the dynamic as well as steady state performance and robustness to parameter uncertainties. The performances of DTFC IMD using different speed control techniques have been tested in MATLAB/Simulink at different operating speed conditions. The simulation results are presented in different operating conditions such as forward and reversal motoring under no-load, load and sudden change in speed conditions.

\section{Mathematical Modeling of Induction Motor}

The mathematical model of IMD is developed using the stator and rotor flux linkage equations, which are referred to a general reference frame [18-19], it is indicated by the superscript ' $a$ ' and the following equations are shown as:

Electrical equations:

Stator flux

$$
: \quad \psi_{\mathrm{dqs}}^{\mathrm{a}}=\mathrm{L}_{\mathrm{s}} \mathrm{i}_{\mathrm{dqs}}^{\mathrm{a}}+\mathrm{L}_{\mathrm{m}} \mathrm{i}_{\mathrm{dqr}}^{\mathrm{a}}
$$

Rotor flux

$$
: \quad \psi_{\mathrm{dqr}}^{\mathrm{a}}=\mathrm{L}_{\mathrm{r}} \mathrm{i}_{\mathrm{dqr}}^{\mathrm{a}}+\mathrm{L}_{\mathrm{m}} \mathrm{i}_{\mathrm{dqs}}^{\mathrm{a}}
$$

Stator voltage

$$
\begin{array}{ll}
: & \mathrm{U}_{\mathrm{ds}}^{\mathrm{a}}=\left(\mathrm{R}_{\mathrm{s}}+\partial \mathrm{L}_{\mathrm{s}}\right) \mathrm{i}_{\mathrm{ds}}^{\mathrm{a}}+\partial \mathrm{L}_{\mathrm{m}} \mathrm{i}_{\mathrm{dr}}^{\mathrm{a}}+\mathrm{j} \omega_{\mathrm{a}} \psi_{\mathrm{qs}}^{\mathrm{a}} \\
: & \mathrm{U}_{\mathrm{qs}}^{\mathrm{a}}=\left(\mathrm{R}_{\mathrm{s}}+\partial \mathrm{L}_{\mathrm{s}}\right) \mathrm{i}_{\mathrm{qs}}^{\mathrm{a}}+\partial \mathrm{L}_{\mathrm{m}} \mathrm{i}_{\mathrm{qr}}^{\mathrm{a}}+\mathrm{j} \omega_{\mathrm{a}} \psi_{\mathrm{ds}}^{\mathrm{a}}
\end{array}
$$

Rotor voltage

$$
\begin{aligned}
& : \quad 0=\left(\mathrm{R}_{\mathrm{r}}+\partial \mathrm{L}_{\mathrm{r}}\right) \mathrm{i}_{\mathrm{dr}}^{\mathrm{a}}+\partial \mathrm{L}_{\mathrm{m}} \mathrm{i}_{\mathrm{ds}}^{\mathrm{a}}-\left(\omega_{\mathrm{a}}-\omega_{\mathrm{r}}\right) \psi_{\mathrm{qr}}^{\mathrm{a}} \\
& : \quad 0=\left(\mathrm{R}_{\mathrm{r}}+\partial \mathrm{L}_{\mathrm{r}}\right) \mathrm{i}_{\mathrm{qr}}^{\mathrm{a}}+\partial \mathrm{L}_{\mathrm{m}} \mathrm{i}_{\mathrm{qs}}^{\mathrm{a}}+\left(\omega_{\mathrm{a}}-\omega_{\mathrm{r}}\right) \psi_{\mathrm{dr}}^{\mathrm{a}}
\end{aligned}
$$

Mechanical equation $\quad: \quad T_{e}-T_{L}=J_{m} \partial \omega_{r}+B_{m} \omega_{r}$ 
Electro-magnetic torque : $\quad \mathrm{T}_{\mathrm{e}}=\frac{3}{2} \frac{\mathrm{P}}{2}\left(\psi_{\mathrm{ds}}^{\mathrm{a}} \mathrm{i}_{\mathrm{qs}}^{\mathrm{a}}-\psi_{\mathrm{qs}}^{\mathrm{a}} \mathrm{i}_{\mathrm{ds}}^{\mathrm{a}}\right)$

The above induction machine model equations are referred to a stationary reference frame. It is simply derived by substituting ' $\omega_{\mathrm{a}}=0$ ' in the Eqs. (3), (4), (5) and (6) and indicated by the superscript ' $p$ ', which is with d-axis attached on the stator phase 'A' winding. The machine model can be rewritten in a stationary frame as follows:

Stator flux

$$
\psi_{\mathrm{dqs}}^{\mathrm{p}}=\mathrm{L}_{\mathrm{s}} \mathrm{i}_{\mathrm{dqs}}^{\mathrm{p}}+\mathrm{L}_{\mathrm{m}} \mathrm{i}_{\mathrm{dqr}}^{\mathrm{p}}
$$

Rotor flux

$$
\psi_{\mathrm{dqr}}^{\mathrm{p}}=\mathrm{L}_{\mathrm{r}} \mathrm{i}_{\mathrm{dqr}}^{\mathrm{p}}+\mathrm{L}_{\mathrm{m}} \mathrm{i}_{\mathrm{dqs}}^{\mathrm{p}}
$$

Stator voltage

$$
\begin{array}{ll}
: & \mathrm{U}_{\mathrm{ds}}^{\mathrm{p}}=\left(\mathrm{R}_{\mathrm{s}}+\partial \mathrm{L}_{\mathrm{s}}\right) \mathrm{i}_{\mathrm{ds}}^{\mathrm{p}}+\partial \mathrm{L}_{\mathrm{m}} \mathrm{i}_{\mathrm{dr}}^{\mathrm{p}} \\
: & \mathrm{U}_{\mathrm{qs}}^{\mathrm{p}}=\left(\mathrm{R}_{\mathrm{s}}+\partial \mathrm{L}_{\mathrm{s}}\right) \mathrm{i}_{\mathrm{qs}}^{\mathrm{p}}+\partial \mathrm{L}_{\mathrm{m}} \mathrm{i}_{\mathrm{qr}}^{\mathrm{p}}
\end{array}
$$

Rotor voltage

$$
\begin{array}{r}
: \quad 0=\left(\mathrm{R}_{\mathrm{r}}+\partial \mathrm{L}_{\mathrm{r}}\right) \mathrm{i}_{\mathrm{dr}}^{\mathrm{p}}+\partial \mathrm{L}_{\mathrm{m}} \mathrm{i}_{\mathrm{ds}}^{\mathrm{p}}+\omega_{\mathrm{r}}\left(\mathrm{L}_{\mathrm{r}} \mathrm{i}_{\mathrm{dr}}^{\mathrm{p}}+\mathrm{L}_{\mathrm{m}} \mathrm{i}_{\mathrm{ds}}^{\mathrm{p}}\right) \\
0=\left(\mathrm{R}_{\mathrm{r}}+\partial \mathrm{L}_{\mathrm{r}}\right) \mathrm{i}_{\mathrm{qr}}^{\mathrm{p}}+\partial \mathrm{L}_{\mathrm{m}} \mathrm{i}_{\mathrm{qs}}^{\mathrm{p}}-\omega_{\mathrm{r}}\left(\mathrm{L}_{\mathrm{r}} \mathrm{i}_{\mathrm{qr}}^{\mathrm{p}}+\mathrm{L}_{\mathrm{m}} \mathrm{i}_{\mathrm{qs}}^{\mathrm{p}}\right)
\end{array}
$$

Mechanical equation $: \quad T_{e}=J \partial \omega_{r}+B \omega_{r}+T_{L}$

Electro-magnetic torque : $\quad \mathrm{T}_{\mathrm{e}}=\frac{3}{2} \frac{\mathrm{P}}{2}\left(\psi_{\mathrm{ds}{ }_{\mathrm{qs}}^{\mathrm{p}}}^{\mathrm{p}}-\psi_{\mathrm{qs}}^{\mathrm{p}} \mathrm{i}_{\mathrm{ds}}^{\mathrm{p}}\right)$

The above two axis stator and rotor voltage state Eqs. (11), (12), (13), and (14) of induction motor in a stationary reference frame can be written in a state space matrix form as:

$$
\left[\begin{array}{c}
\mathrm{U}_{\mathrm{ds}}^{\mathrm{a}} \\
\mathrm{U}_{\mathrm{qs}}^{\mathrm{a}} \\
0 \\
0
\end{array}\right]=\left[\begin{array}{cccc}
\mathrm{R}_{\mathrm{s}}+\mathrm{L}_{\mathrm{s}} \partial & 0 & \mathrm{~L}_{\mathrm{m}} \partial & 0 \\
0 & \mathrm{R}_{\mathrm{s}}+\mathrm{L}_{\mathrm{s}} \partial & 0 & \mathrm{~L}_{\mathrm{m}} \partial \\
\mathrm{L}_{\mathrm{m}} \partial & \omega_{\mathrm{r}} \mathrm{L}_{\mathrm{m}} & \mathrm{R}_{\mathrm{r}}+\mathrm{L}_{\mathrm{r}} \partial & \omega_{\mathrm{r}} \mathrm{L}_{\mathrm{r}} \\
-\omega_{\mathrm{r}} \mathrm{L}_{\mathrm{m}} & \mathrm{L}_{\mathrm{m}} \partial & -\omega_{\mathrm{r}} \mathrm{L}_{\mathrm{r}} & \mathrm{R}_{\mathrm{r}}+\mathrm{L}_{\mathrm{r}} \partial
\end{array}\right]\left[\begin{array}{c}
\mathrm{i}_{\mathrm{ds}}^{\mathrm{a}} \\
\mathrm{i}_{\mathrm{qs}}^{\mathrm{a}} \\
\mathrm{i}_{\mathrm{dr}}^{\mathrm{a}} \\
\mathrm{i}_{\mathrm{qr}}^{\mathrm{a}}
\end{array}\right]
$$

The two-axis (d-q) stator and rotor current as the state variables of IMD is acquired by rewritten matrix Eq. (17) as:

$$
\begin{aligned}
& \frac{\mathrm{d}}{\mathrm{dt}}(\mathrm{X})=\mathrm{AX}+\mathrm{BU} \\
& \mathrm{X}=\left[\begin{array}{llll}
\mathrm{i}_{\mathrm{ds}}^{\mathrm{p}} & \mathrm{i}_{\mathrm{qs}}^{\mathrm{p}} & \mathrm{i}_{\mathrm{dr}}^{\mathrm{p}} & \mathrm{i}_{\mathrm{qr}}^{\mathrm{p}}
\end{array}\right]^{\mathrm{T}} ; \quad \mathrm{U}=\left[\begin{array}{llll}
\mathrm{U}_{\mathrm{ds}}^{\mathrm{p}} & \mathrm{U}_{\mathrm{qs}}^{\mathrm{p}} & 0 & 0
\end{array}\right]^{\mathrm{T}} \\
& \mathrm{A}=\frac{1}{\mathrm{~L}_{\sigma}}\left[\begin{array}{cccc}
-\mathrm{R}_{\mathrm{s}} \mathrm{L}_{\mathrm{r}} & \omega_{\mathrm{r}} \mathrm{L}_{\mathrm{m}}^{2} & \mathrm{R}_{\mathrm{r}} \mathrm{L}_{\mathrm{m}} & \omega_{\mathrm{r}} \mathrm{L}_{\mathrm{r}} \mathrm{L}_{\mathrm{m}} \\
-\omega_{\mathrm{r}} \mathrm{L}_{\mathrm{m}}^{2} & -\mathrm{R}_{\mathrm{s}} \mathrm{L}_{\mathrm{r}} & -\omega_{\mathrm{r}} \mathrm{L}_{\mathrm{r}} \mathrm{L}_{\mathrm{m}} & \mathrm{R}_{\mathrm{r}} \mathrm{L}_{\mathrm{m}} \\
\mathrm{L}_{\mathrm{m}} \mathrm{R}_{\mathrm{s}} & -\omega_{\mathrm{r}} \mathrm{L}_{\mathrm{s}} \mathrm{L}_{\mathrm{m}} & -\mathrm{R}_{\mathrm{r}} \mathrm{L}_{\mathrm{s}} & -\omega_{\mathrm{r}} \mathrm{L}_{\mathrm{s}} \mathrm{L}_{\mathrm{r}} \\
\omega_{\mathrm{r}} \mathrm{L}_{\mathrm{s}} \mathrm{L}_{\mathrm{m}} & \mathrm{R}_{\mathrm{s}} \mathrm{L}_{\mathrm{m}} & \omega_{\mathrm{r}} \mathrm{L}_{\mathrm{s}} \mathrm{L}_{\mathrm{r}} & -\mathrm{R}_{\mathrm{r}} \mathrm{L}_{\mathrm{s}}
\end{array}\right] ; \mathrm{B}=\frac{1}{\mathrm{~L}_{\sigma}}\left[\begin{array}{cc}
\mathrm{L}_{\mathrm{r}} & 0 \\
0 & \mathrm{~L}_{\mathrm{r}} \\
-\mathrm{L}_{\mathrm{m}} & 0 \\
0 & -\mathrm{L}_{\mathrm{m}}
\end{array}\right]
\end{aligned}
$$


Where $\partial=\mathrm{d} / \mathrm{dt}, \mathrm{L}_{\sigma}=\mathrm{L}_{\mathrm{s}} \mathrm{L}_{\mathrm{r}}-\mathrm{L}_{\mathrm{m}}^{2}, i_{d s}, i_{d r}: \mathrm{d}$-axis stator and rotor current, $i_{q s}, i_{q r}:$ q-axis stator and rotor current, $\psi_{d s}, \psi_{d r}:$ d-axis stator and rotor flux linkages, $\psi_{q s}, \psi_{q r}:$ q-axis stator and rotor flux linkages, $L_{s}, L_{r}$ : stator and rotor leakage inductances, $L_{m}$ : mutual inductance, $R_{s}$, $R_{r}$ : stator and rotor resistances, $P$ : number of poles, and $T_{e}$ : electromagnetic torque.

\section{Direct Torque and Flux Control}

The schematic model of direct torque and flux control (DTFC) IMD is shown in Figure. 1. The principle of DTFC is to directly control the stator flux and electromagnetic toque without using coordinate transformation and current regulators, unlike vector control or FOC. The flux and torque hysteresis band controllers are trigger one of the eight possible (six active and two zero) voltage vectors which is generated by two level voltage source inverter (VSI) to keep the stator flux and torque ripples within the hysteresis band limits. Proper selection of voltage vectors allows a decoupled control of stator flux and torque.

The stator flux $\left(\psi_{\mathrm{s}}\right)$ is estimated using the measured stator current and voltages, which is given by:

$$
\psi_{\mathrm{s}}=\sqrt{\left(\psi_{\mathrm{ds}}^{\mathrm{p} 2}+\psi_{\mathrm{qs}}^{\mathrm{p} 2}\right)}
$$

Where

$$
\psi_{\mathrm{ds}}^{\mathrm{p}}=\int\left(\mathrm{U}_{\mathrm{ds}}^{\mathrm{p}}-\mathrm{i}_{\mathrm{ds}}^{\mathrm{p}} \mathrm{R}_{\mathrm{s}}\right) \mathrm{dt} ; \quad \psi_{\mathrm{qs}}^{\mathrm{p}}=\int\left(\mathrm{U}_{\mathrm{qs}}^{\mathrm{p}}-\mathrm{i}_{\mathrm{qs}}^{\mathrm{p}} \mathrm{R}_{\mathrm{s}}\right) \mathrm{dt}
$$

The expression for estimating electromagnetic torque and angle between the stator and rotor flux are:

$$
\begin{aligned}
\mathrm{T}_{\mathrm{e}} & =\frac{3}{2} \frac{\mathrm{P}}{2}\left(\psi_{\mathrm{ds}}^{\mathrm{p}} \mathrm{i}_{\mathrm{qs}}^{\mathrm{p}}-\psi_{\mathrm{qs}}^{\mathrm{p}} \mathrm{i}_{\mathrm{ds}}^{\mathrm{p}}\right) \\
\theta_{\mathrm{e}}(\mathrm{k}) & =\tan ^{-1}\left(\frac{\psi_{\mathrm{qs}}^{\mathrm{p}}}{\psi_{\mathrm{ds}}^{\mathrm{p}}}\right)
\end{aligned}
$$

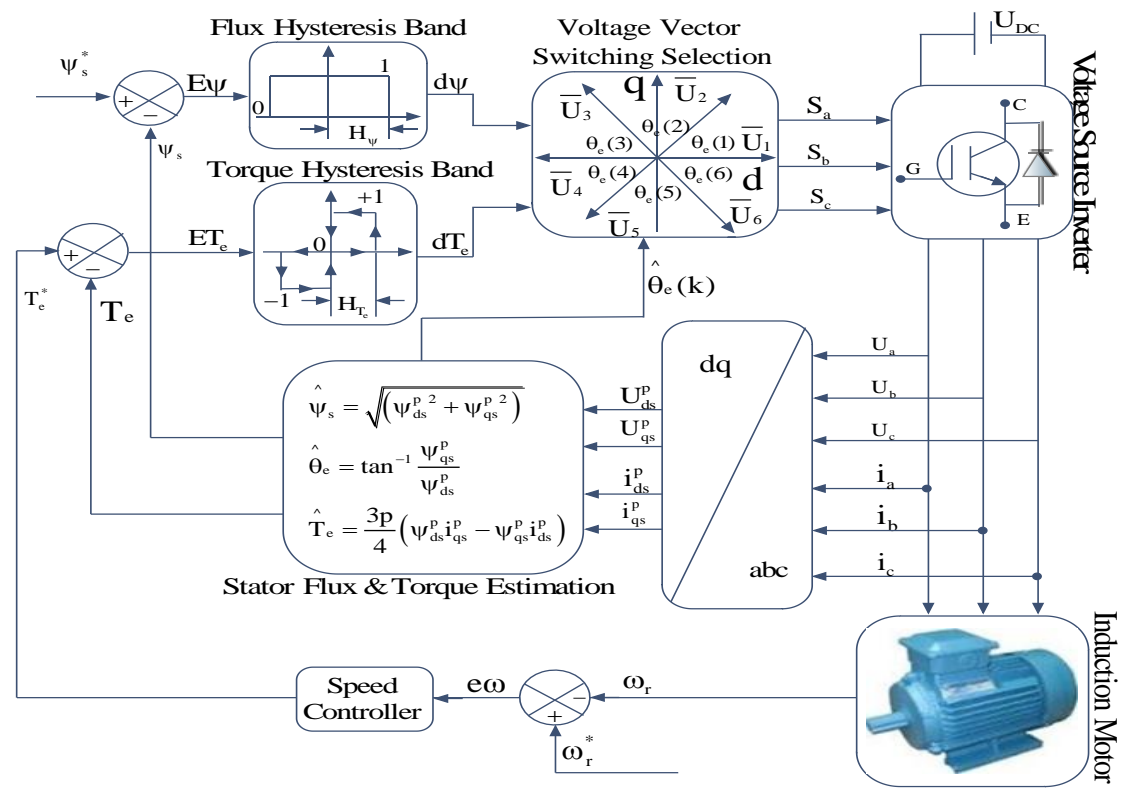

Figure 1. Schematic model of direct torque and Flux control induction motor drive 


\section{Construction of Speed Controller}

The high performance of the IMD is largely depended upon the choice of the robust speed controller.

\section{A. Construction of PI-Speed Controller}

The conventional PI-speed controller (PISC) requires precise mathematical model of the system and appropriate gain values of $\mathrm{K}_{\mathrm{p}}$ (proportional gain) and $\mathrm{K}_{\mathrm{i}}$ (integral gain) to achieve high performance drive. The gain values of $K_{p}=30$ and $K_{i}=2$ are obtained based on hit and trial method.

$$
\mathrm{T}_{\mathrm{e}}^{*}=\left(\mathrm{k}_{\mathrm{p}}+\frac{\mathrm{k}_{\mathrm{i}}}{\mathrm{s}}\right) \mathrm{e} \omega_{\mathrm{r}}
$$

\section{B. Sliding Mode Speed Controller}

The sliding mode speed control (SMSC) is a nonlinear, adaptive control structure and offers an effective and robust control performance in load disturbance condition. The system response is insensitive to motor parameter uncertainties, as IMD is a multivariable and nonlinear system, it faces lot of disturbances during experimental implementation. The SMSC scheme is implemented to replace the PISC. The SMSC principle defines a high speed switching control law to drive the nonlinear state trajectory onto a switching surface and maintain the state trajectory on sliding surface for all subsequent interval of time [12]. The system response in the phase plane is forced to follow a sliding surface. The dynamics of error speed ' $\mathrm{e} \omega_{\mathrm{r}}$ ' and its derivative error speed ' $\Delta \mathrm{e} \omega_{\mathrm{r}}$ ' need to be driven to zero along the sliding surface $\mathrm{s}(\mathrm{t})=0$. In time domain, the corresponding response is exponentially decaying to zero. Its time constant ( $\lambda$ ) depends on the slope of the sliding surface and the control signal forces the response to slide on the sliding surface and the system state error always remains on zero state [13-15]. This switching process easily implemented by using back and forth between positive and negative controller gains. The system error not only made zero, but also independent on the IM parameter variations. To design a SMSC, it starts by defining the error speed as:

$$
\mathrm{e} \omega_{\mathrm{r}}=\omega_{\mathrm{r}}^{*}-\omega_{\mathrm{r}}
$$

The Eq. (15) can be rewritten as:

$$
\dot{\omega}_{\mathrm{r}}=-\frac{\mathrm{B}}{\mathrm{J}} \omega_{\mathrm{r}}+\frac{1}{\mathrm{~J}}\left(\mathrm{~T}_{\mathrm{e}}-\mathrm{T}_{\mathrm{L}}\right)
$$

Where $\mathrm{a}=\mathrm{B} / \mathrm{J} ; \mathrm{d}=\mathrm{T} / \mathrm{J} ; \mathrm{b}=1 / \mathrm{J}$

Consider the electromechanical Eq. (24) with uncertainties is shown in Eq. (25):

$$
\dot{\omega}_{\mathrm{r}}=-\mathrm{a} \omega_{\mathrm{r}}+\mathrm{bT} \mathrm{T}_{\mathrm{e}}-\mathrm{d}=-(\mathrm{a}+\Delta \mathrm{a}) \omega_{\mathrm{r}}+(\mathrm{b}+\Delta \mathrm{b}) \mathrm{T}_{\mathrm{e}}-(\mathrm{d}+\Delta \mathrm{d})=\mathrm{f}(\mathrm{t})+\mathrm{x}(\mathrm{t})
$$

Where $\mathrm{f}(\mathrm{t})=-\mathrm{a} \omega_{\mathrm{r}}+\mathrm{bT} \mathrm{T}_{\mathrm{e}}-\mathrm{d} ; \mathrm{x}(\mathrm{t})=-\Delta \mathrm{a} \omega_{\mathrm{r}}+\Delta \mathrm{bT}-\Delta \mathrm{d}$ and $\Delta \mathrm{a}, \Delta \mathrm{b}$ and $\Delta \mathrm{d}$ denotes the external disturbances and uncertainties of the terms $a, b$ and $d$, respectively.

Taking the time derivative of error speed Eq. (23) and substituting the expression of $\omega_{\mathrm{r}}$ from Eq. (25) gives:

$$
\mathrm{e} \omega_{\mathrm{r}}=\omega_{\mathrm{r}}-(\mathrm{f}(\mathrm{t})+\mathrm{x}(\mathrm{t}))
$$


The sliding surface $s(t)=0$ with integral components can be defining as:

$$
\mathrm{s}(\mathrm{t})=\mathrm{e} \omega_{\mathrm{r}}(\mathrm{t})+\lambda \int_{0}^{\mathrm{t}} \mathrm{e} \omega_{\mathrm{r}}(\mathrm{t})=0 \quad \lambda>0
$$

Where, $\lambda$ is the positive constant gain and it depends on bandwidth of the system.

Taking time derivative of the sliding surface $s(t)=0$ in the Eq. (27). The error dynamics at the sliding surface $\mathrm{s}(\mathrm{t})=0$ will be forced to exponentially decay to zero. The best approximation of input control without uncertainties is expressed as:

$$
\dot{\mathrm{s}}=\dot{\omega}_{\mathrm{r}}-\mathrm{f}(\mathrm{t})+\lambda \mathrm{e} \omega_{\mathrm{r}}=\mathrm{h}(\mathrm{t})
$$

The SMC law can be found using Lyapunov theory and defining the Lyapunov function as

$$
\mathrm{v}=1 / 2 \mathrm{~s}^{2}
$$

According to Lyapunov's method, it is found that $\mathrm{v}(\mathrm{t})$ is clearly positive definite and the derivative of $\mathrm{v}(\mathrm{t})$ is negative definite, this means the state trajectory will be driven and attracted toward the sliding line ' $\mathrm{s}$ ' and once it reaches sliding surface, then it will remain on the sliding surface. Taking the time derivative of the Eq. (29) and substitute the Eq (28) in Eq (30), then the Lyapunov function is given as:

$$
\dot{\mathrm{v}}=\mathrm{si}=\mathrm{s}(\mathrm{h}(\mathrm{t}))
$$

The Eq (30) is negative definite if:

$$
\mathrm{h}(\mathrm{t}) \begin{cases}<0 & \text { for } \mathrm{s}>0 \\ =0 & \text { for } \mathrm{s}=0 \\ >0 & \text { for } \mathrm{s}<0\end{cases}
$$

The switching control law is defined as:

$$
u_{s}=-\beta \operatorname{sgn}(s) ; \operatorname{sgn}(s)= \begin{cases}-1 & \text { for } s<0 \\ +1 & \text { for } s>0\end{cases}
$$

Where, $\operatorname{sgn}(s)$ is signum of ' $s$ ' function and ' $\beta$ ' is a positive constant of respective switching gain and must be choosen as greater than the total uncertainties present in corresponding model guaranteed by the Lyapunov stability principle. Unfortunately, the use of signum function causes high switching frequency chattering phenomenon due to discontinues control action, which creates problem when the system state is close to the sliding surface. In [20] J. J. E. Slotine has introduced the boundary layer of width ' $\phi$ ' on both side of the switching surface to reduce the chattering phenomenon is shown in Figure. 6 (b). Then the Eq. (32) can be modified as:

$$
u_{\mathrm{s}}=-\beta \mathrm{sat}\left(\frac{\mathrm{s}}{\phi}\right) ; \quad \mathrm{s} \text { at }\left(\frac{\mathrm{s}}{\phi}\right)= \begin{cases}\mathrm{s} / \phi & \text { for }|\mathrm{s}| \leq \phi \\ \operatorname{sgn}(\mathrm{s}) & \text { for }|\mathrm{s}|>\phi\end{cases}
$$

Where ' $\phi$ ' represent the thickness of the boundary layer. 
The ' $\mathrm{u}_{\mathrm{eq}}$ ' is a best approximation input control without uncertainties. Then, the sliding mode speed controller is designated as:

$$
\mathrm{T}_{\mathrm{e}}=\mathrm{u}_{\mathrm{eq}}+\mathrm{u}_{\mathrm{s}} ; \mathrm{T}_{\mathrm{e}}=\frac{1}{\mathrm{~b}}\left(\dot{\omega}_{\mathrm{r}}^{*}+\mathrm{a} \omega_{\mathrm{r}}+\mathrm{d}+\lambda \mathrm{e} \omega_{\mathrm{r}}-\beta \mathrm{sat}\left(\frac{\mathrm{s}}{\phi}\right)\right)=\mathrm{T}_{\mathrm{e}}^{*}
$$

\section{Fuzzy Logic Speed Controller}

The Fuzzy logic speed controller (FLSC) is a adaptive control approach and offers robust performance with parameter uncertainties. The FLSC can handle complicated nonlinear systems which have a degree of uncertainty. It does not require precise mathematical modeling and parameters unlike PISC, which makes the controller suitable for the induction motor control [19]. The FLSC has two input variables, error speed ' $\mathrm{e} \omega_{\mathrm{r}}$ ' see in Eq. (23) and rate of change in error speed ' $\Delta \omega_{\mathrm{r}}$ ' in Eq. (35). The actual speed ' $\omega_{\mathrm{r}}$ ' is compared with a set reference speed ' $\omega_{\mathrm{r}}^{*}$ '. The error speed signal ' $\mathrm{e} \omega_{\mathrm{r}}$ ' is then processed through a FLSC, which contributes to zero steady error in tracking the reference speed signal. The block diagram of a FLSC is shown in Figureure 2.

$$
\Delta \mathrm{e} \omega_{\mathrm{r}}(\mathrm{k})=\mathrm{e} \omega_{\mathrm{r}}(\mathrm{k})-\mathrm{e} \omega_{\mathrm{r}}(\mathrm{k}-1)
$$

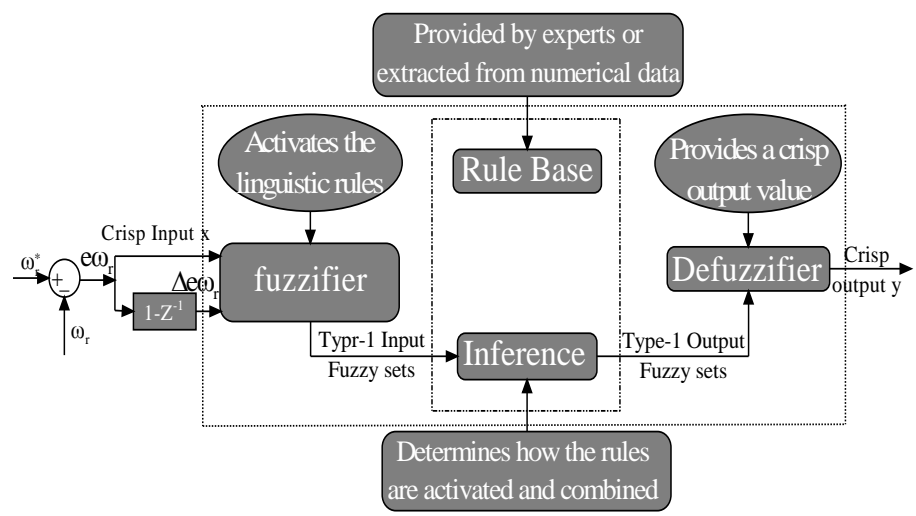

Figure 2. Block diagram of fuzzy logic speed control (FLSC).

\section{C.1. Fuzzy inference system}

The Fuzzy Inference System (FIS) is a popular computing framework based on the concepts of fuzzy set theory, fuzzy IF-THEN rules and fuzzy reasoning. It has found successful applications in a wide variety of fields, such as expert systems, robotics, time-series prediction, data classification automatic control, pattern recognition, and decision analysis. Because of its multi-disciplinary nature, the FIS is known by various other names, such as fuzzy expert system, fuzzy rule based system, fuzzy model, fuzzy associative memory, fuzzy logic controller and simply fuzzy system.

The basic structure of a FIS consists of three components; a data base, which describes the membership functions (M.Fs) used in the fuzzy rules, a rule base, which contains a selection of rules and a reasoning mechanism, which performs the inference technique upon the fuzzy rules and given facts to derive a reasonable output.

The basic FIS can take either crisp inputs or fuzzy singletons, but it produces output, which are almost always fuzzy sets. Sometimes it is necessary to have a crisp output, especially in a position where a FIS is used as a controller. Therefore, we need a method of defuzzification to extract a crisp value that best represents a fuzzy set. A FIS with a crisp output is shown in 
Figure. 3. Where the dashed line indicates a basic fuzzy inference system with fuzzy output and defuzzification block serves the purpose of transforming an output fuzzy set into a crisp value.

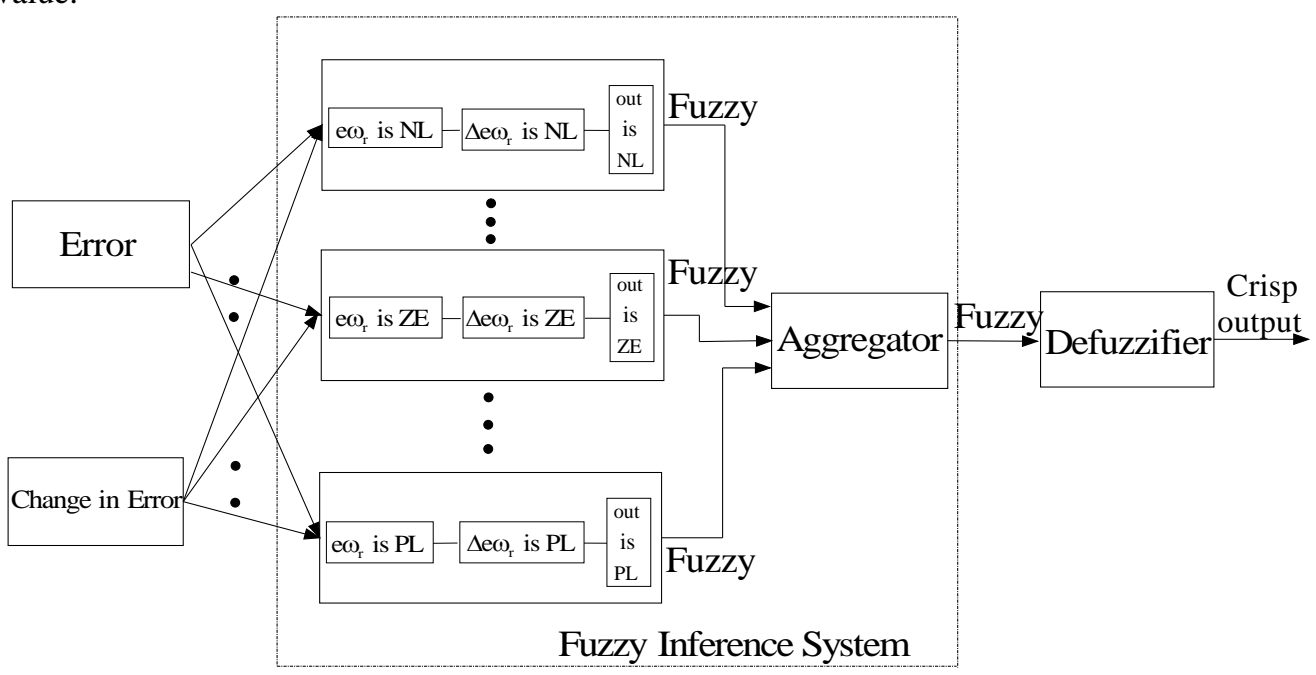

Figure 3. Block diagram of fuzzy inference system.

\section{C.2. Construction of Fuzzy Inference System}

The fuzzy inference system (FIS) is designed (selected) using MATLAB/Simulink shown in Figure 4.

* No. of inputs and outputs $(2-\mathrm{i} / \mathrm{p}$ and $1-\mathrm{o} / \mathrm{p})$,

* No. of rules (25 rules),

* Type of membership function (triangular),

* No. of membership functions (Five),

* Type of implication (Mamdani Max-min operation),

* Type of defuzzification method (centroid of area method).

The FIS consists of 1. Fuzzy inference system (FIS) editor, 2. Membership function (MF) editor, 3. Rule editor, 4. Rule viewer, and 5. Surface viewer.

The FIS editor handles the high-level control issues for the system: How many input variables and output variables are required and give their names. The M.F editor is used to describe the shapes of all the input and output M.Fs associated with each variable. The rule editor is used for adding or removing the list of fuzzy rules that define the performance of the system. In the present model 25 rules are developed. The rule viewer and the surface viewer are used for looking at, as opposed to editing, the FIS. They are strictly read-only tools. Used as a diagnostic, it can show which rules are active, or how individual MF shapes are influencing the responses. The surface viewer is used to display the dependency of one of the outputs on any one (error speed) or two (error speed and change in error speed) of the inputs, it generates and plots an output surface map for the system. 


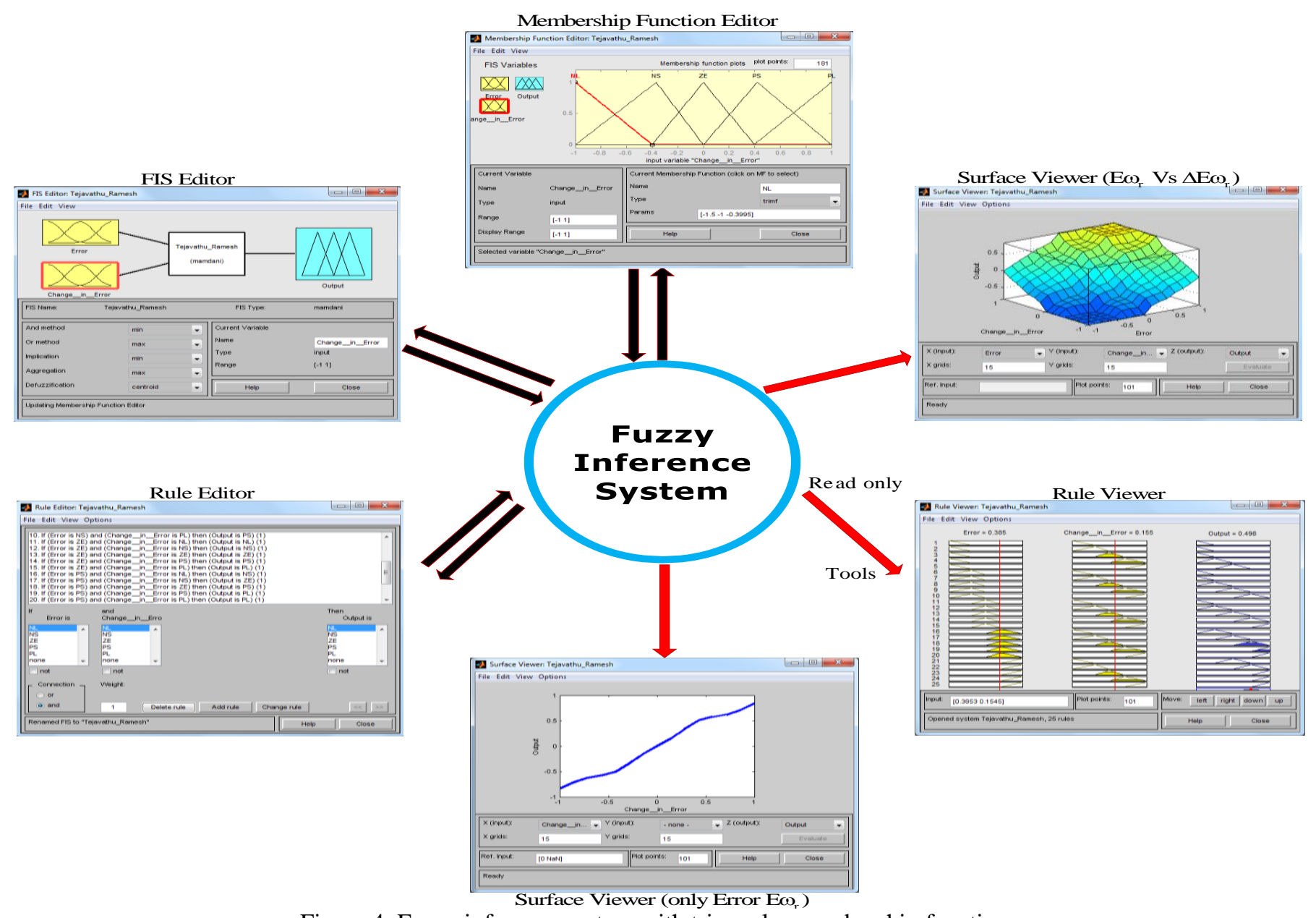

Figure 4. Fuzzy inference system with triangular membership function. 


\section{C.3. Design of defuzzification}

The rules of the FLC generate required output in a linguistic variable (fuzzy number), according to the real world requirements and the linguistic variables have to be transformed to crisp output.

$$
\mu_{\mathrm{A}}(\mathrm{x})=\operatorname{defuzz}(\mathrm{x}, \mathrm{mf}, \mathrm{Type})
$$

Where defuzz(x, mf, Type) returns a defuzzified value out, of a M.F positioned at associated variable value $\mathrm{x}$, using one of several defuzzification strategies, according to the argument Type. The variable type can be one of the following: COA: centroid of area, BOA: bisector of area, MOM: mean value of maximum, SOM: smallest (absolute) value of maximum and LOM: largest (absolute) value of maximum. After the inference step, the overall result is a fuzzy value. This result should be defuzzified to obtain a final crisp output. For the defuzzification purpose, the centroid of area (COA) method (often called the center of gravity) is chosen in this paper. Centroid defuzzification returns the center of area under the curve. The mathematical expression of centroid of area (COA) can be as follows:

$$
C O A=\frac{\int_{a}^{b} \mu_{A}(x) x d x}{\int_{a}^{b} \mu_{A}(x) d x}
$$

With a discretized universe of discourse, the expression is

$$
C O A=\frac{\sum_{i=1}^{n} \mu_{A}(x) \quad x d x}{\sum_{i=1}^{n} \mu_{A}(x)}
$$

The triangular curve is a function of vector $\mathrm{x}$, and depends on three scalar parameters $\mathrm{a}, \mathrm{b}$, and $\mathrm{c}$ are shown in the Eq. (39):

$$
\mu_{\mathrm{A}}(\mathrm{x})=\max \left(\min \left(\frac{\mathrm{x}-\mathrm{a}}{\mathrm{b}-\mathrm{a}}\right),\left(\frac{\mathrm{c}-\mathrm{x}}{\mathrm{c}-\mathrm{b}}\right), 0\right)
$$

\section{C.4. Design of Fuzzy Rule Base}

The FLC converts a linguistic control strategy into an automatic control strategy, and fuzzy rules are constructed by an expert knowledge or experience database. The FLSC rule base design involves defining rules that relate the input variables to the output model properties. Initially, the error speed ' $\mathrm{e} \omega_{\mathrm{r}}$ ' and the rate of change in error speed ' $\Delta \mathrm{e} \omega_{\mathrm{r}}$ ' have been placed in the input variables of the FLSC. Then the output variable of the FLSC generates the controlled reference torque ' $T_{e}^{*}$ '. The fuzzy rules are expressed in English like language with syntax such as; If \{error speed ' $\mathrm{e} \omega_{\mathrm{r}}$ ' is $\mathrm{X}$ and rate of change of error speed ' $\Delta \mathrm{e} \omega_{\mathrm{r}}$ ' is $\left.\mathrm{Y}\right\}$ then $\{$ control output ' $\mathrm{T}_{\mathrm{e}}^{*}$ ' is $\mathrm{Z}$ \}. To convert these numerical variables into linguistic variables, the following five fuzzy levels or sets are chosen as: NL (negative large), NS (negative small), ZE (zero), PS (positive small), and PL (positive large) and summarized in Table 1. These five MFs are same for the input and output variables and characterized using triangular M.F [19, 21], as it can be seen in figure. 5 .

Rule 1: If error speed $\left(e \omega_{\mathrm{r}}\right)$ is "NL" and change_in_error speed $\left(\Delta \mathrm{e} \omega_{\mathrm{r}}\right)$ is "NL" then output $\left(\mathrm{T}_{\mathrm{e}}^{*}\right)$ is "NL", 
Rule 13: If error speed $\left(\mathrm{e}_{\mathrm{r}}\right)$ is "ZE" and change_in_error speed $\left(\Delta \mathrm{e} \omega_{\mathrm{r}}\right)$ is "ZE" then output $\left(\mathrm{T}_{\mathrm{e}}^{*}\right)$ is " $\mathrm{ZE}$ ",

Rule 25: If error speed $\left(e \omega_{\mathrm{r}}\right)$ is "PL" and change_in_error speed $\left(\Delta \mathrm{e} \omega_{\mathrm{r}}\right)$ is "PL" then output $\left(T_{e}^{*}\right)$ is "PL".

(i)
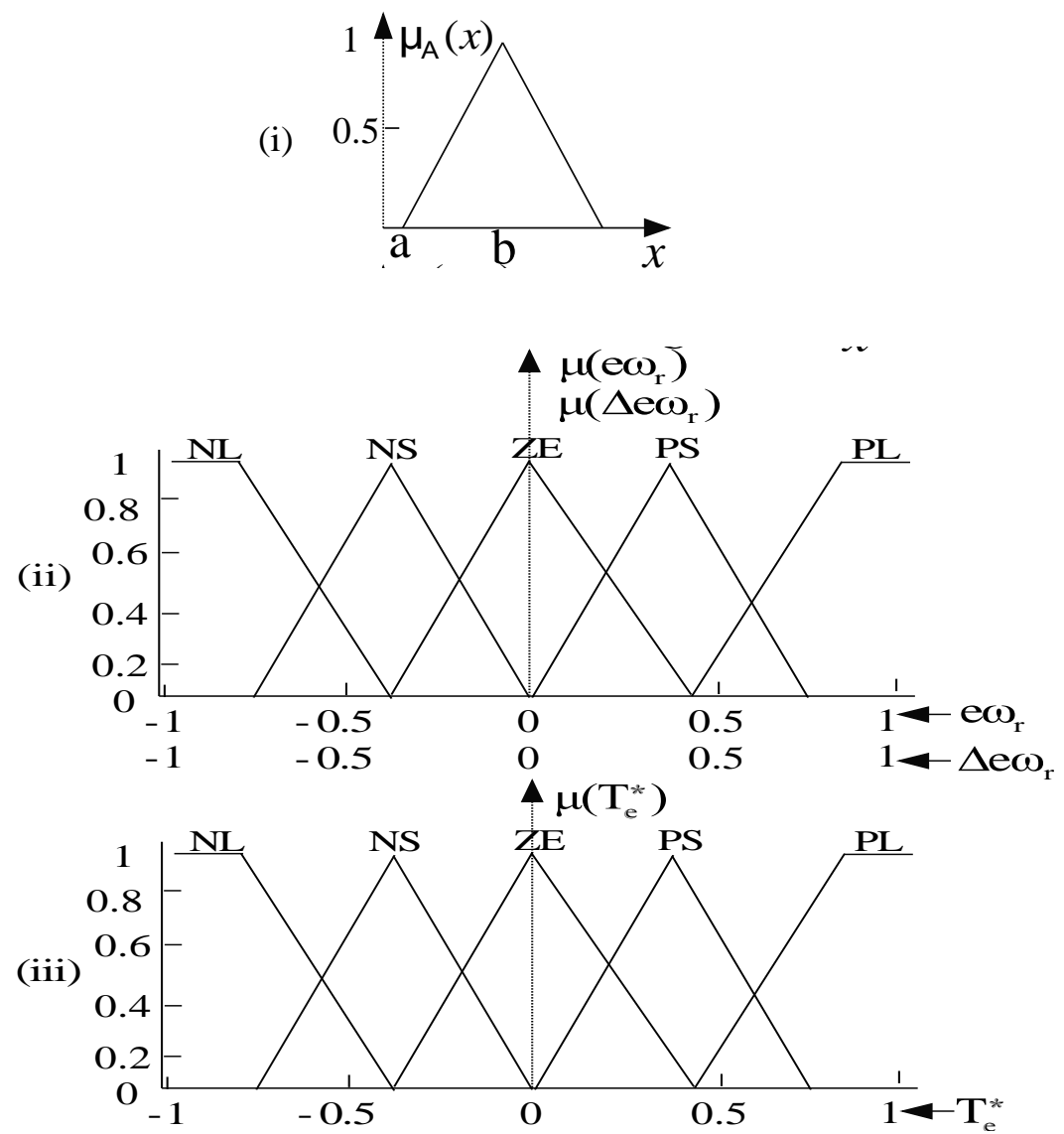

Figure 5. The fuzzy input variables (i). Triangular M. F, (ii) error speed $\left(e \omega_{\mathrm{r}}\right)$ and change in error speed $\left(\Delta \mathrm{e}_{\mathrm{r}}\right)$ normalized Triangular M. F and output variable (iii) reference torque $\left(\mathrm{T}_{\mathrm{e}}^{*}\right)$ normalized Triangular M. F.

Table 1. Fuzzy logic control rules

\begin{tabular}{clllll}
\hline $\mathrm{NL} \omega_{\mathrm{r}}(\mathrm{t})$ & $\mathrm{NL}$ & $\mathrm{NS}$ & $\mathrm{ZE}$ & $\mathrm{PS}$ & $\mathrm{PL}$ \\
\hline $\mathrm{NS}$ & $\mathrm{NL}$ & $\mathrm{NL}$ & $\mathrm{NL}$ & $\mathrm{NS}$ & $\mathrm{ZE}$ \\
$\mathrm{NL}$ & $\mathrm{NL}$ & $\mathrm{NL}$ & $\mathrm{NS}$ & $\mathrm{ZE}$ & $\mathrm{PS}$ \\
$\mathrm{ZE}$ & $\mathrm{NL}$ & $\mathrm{NS}$ & $\mathrm{ZE}$ & $\mathrm{PS}$ & $\mathrm{PL}$ \\
$\mathrm{PS}$ & $\mathrm{NS}$ & $\mathrm{ZE}$ & $\mathrm{PS}$ & $\mathrm{PL}$ & $\mathrm{PL}$ \\
$\mathrm{PL}$ & $\mathrm{ZE}$ & $\mathrm{PS}$ & $\mathrm{PL}$ & $\mathrm{PL}$ & $\mathrm{PL}$ \\
\hline
\end{tabular}




\section{Fuzzy Sliding Mode Speed Controller}

The fuzzy sliding mode speed controller (FSMSC) scheme is replacing the PISC to minimising the chattering phenomenon with combine the fuzzy logic controller (FLC) and a sliding mode control (SMC) schemes. The FSMSC scheme serves robustness in parameter uncertainties and ensures the system stability and also improves the system performance. The design of SMC includes the selection of sliding surface and the control law. To eliminate the chattering, usually a boundary layer is introduced neighbouring the sliding surface and the control law, it is written in Eq. 33.

(a)

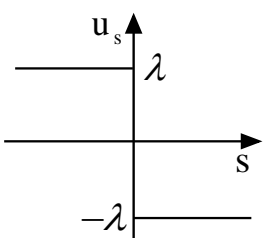

(b)

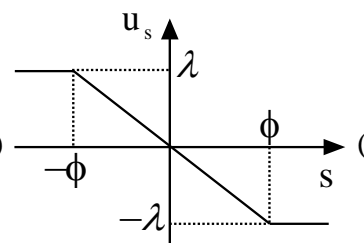

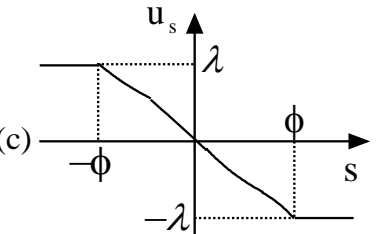

Figure 6. Switching function are: (a) sliding-mode, (b) sliding-mode with boundary layer and (c) fuzzy sliding mode.

From the Eq. 33, it is clear that the system robustness becomes highly dependent on the boundary layer thickness. The selection of ' $\phi$ 'is crucial. If the $|s| \geq \phi$ system states move toward the sliding surface and if the $|s|<\phi$, the control changes linearly and chattering is minimized. But, with the boundary layer introduction, a steady state error problem appears [22]. The smaller value of ' $\phi$ ' may not solve the chattering problem with the less steady state error and with the larger value of ' $\phi$ 'may increase the steady state error. To minimize the steady state error and chattering phenomenon as well as achieve fast dynamic response, the switching control law of $-\lambda$ sat $(\mathrm{s} / \phi)$ is replaced by a FIS in shown in Figure. 7 . Here, the FIS is employed to improve the system dynamic as well as steady state performance and also minimize the steady state error, as a result the selection of boundary layer thickness limit of SMSC is relaxed to some extent. The schematic model of FSMSC and the Mamdadi triangular M.F based input-output variables of FLSC are shown in figure 7 and figure 5 .

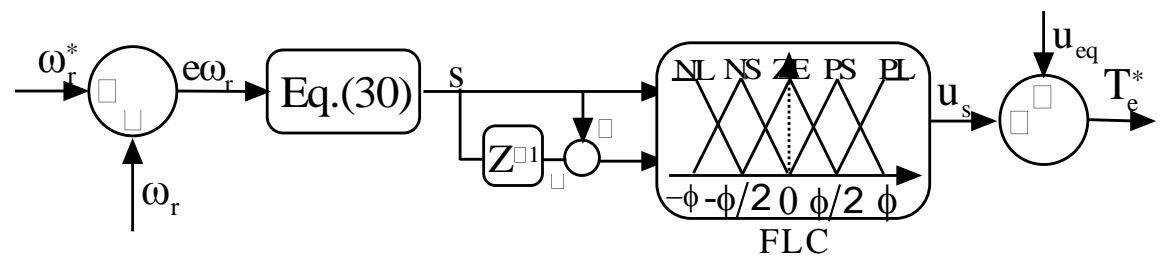

Figure 7. Schematic model of fuzzy sliding mode speed controller (FSMSC).

\section{Simulation Results}

In order to verify the effectiveness of the SMSC, FLSC and FSMSC schemes has been simulated using MATLAB/Simulink environment. For MATLAB/Simulink implementation, we have been considered 4-pole machine with a power rating of $1.5 \mathrm{~kW}$ and rated speed of $1440 \mathrm{rpm}$ induction motor. The IM model is developed using the parameter values are shown in the Table 2.

The performance of IMD is tested under no-load torque with a reference flux $\psi_{\mathrm{s}}^{*}=1 \mathrm{~Wb}$ and reference speed $\omega_{\mathrm{r}}^{*}=1200 \mathrm{rpm}$ in forward motoring mode is shown in Figure. 8 (a). The motor speed reaches its reference speed $+1200 \mathrm{rpm}$ at $0.614 \mathrm{sec}$ using PISC, $0.585 \mathrm{sec}$ using SMSC and $0.573 \mathrm{sec}$ using FSMSC scheme with less ripple contents of torque and stator current 
compared to PISC. Then the IMD is tested under no-load operating condition with $+900 \mathrm{rpm}$ speed is shown in Figure. 9 (a).

Table 2. Parameter and values of induction motor drive

\begin{tabular}{lc}
\hline \multicolumn{1}{c}{ Parameters } & Nominal values \\
\hline Stator Resistance (Rs) & $1.57 \Omega$ \\
Rotor Resistance (Rr) & $1.21 \Omega$ \\
Mutual Inductance (Lm) & $0.165 \mathrm{H}$ \\
Stator Inductance (Ls) & $0.17 \mathrm{H}$ \\
Rotor Inductance (Lr) & $0.17 \mathrm{H}$ \\
Inertia (J) & $0.089 \mathrm{Kg} \cdot \mathrm{m}^{2}$ \\
Frequency (F) & $50 \mathrm{~Hz}$ \\
Speed $\left(\mathrm{W}_{\mathrm{e}}\right)$ & $1440 \mathrm{RPM}$ \\
\hline
\end{tabular}
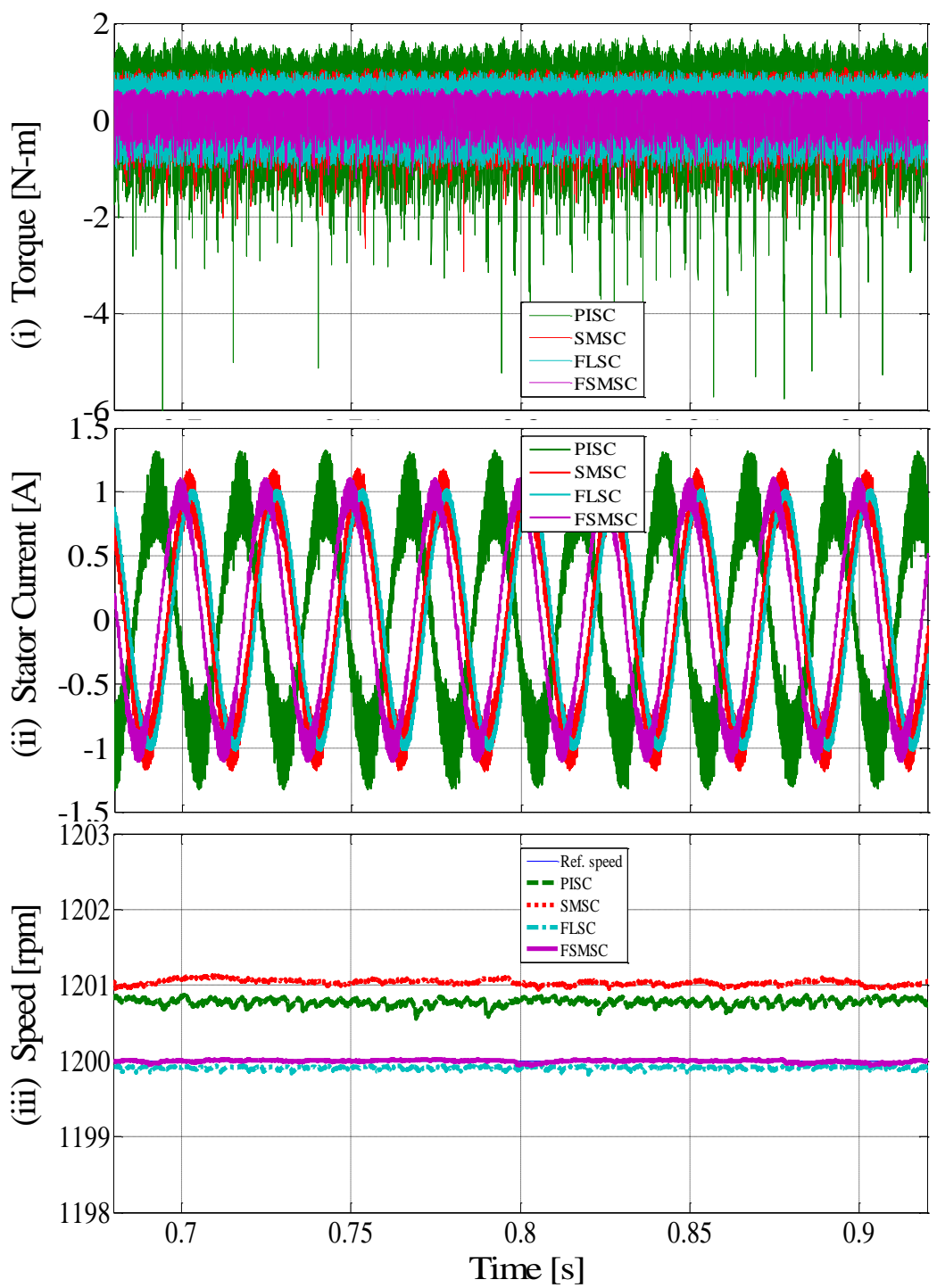

(a). 
Tejavathu Ramesh, et al.
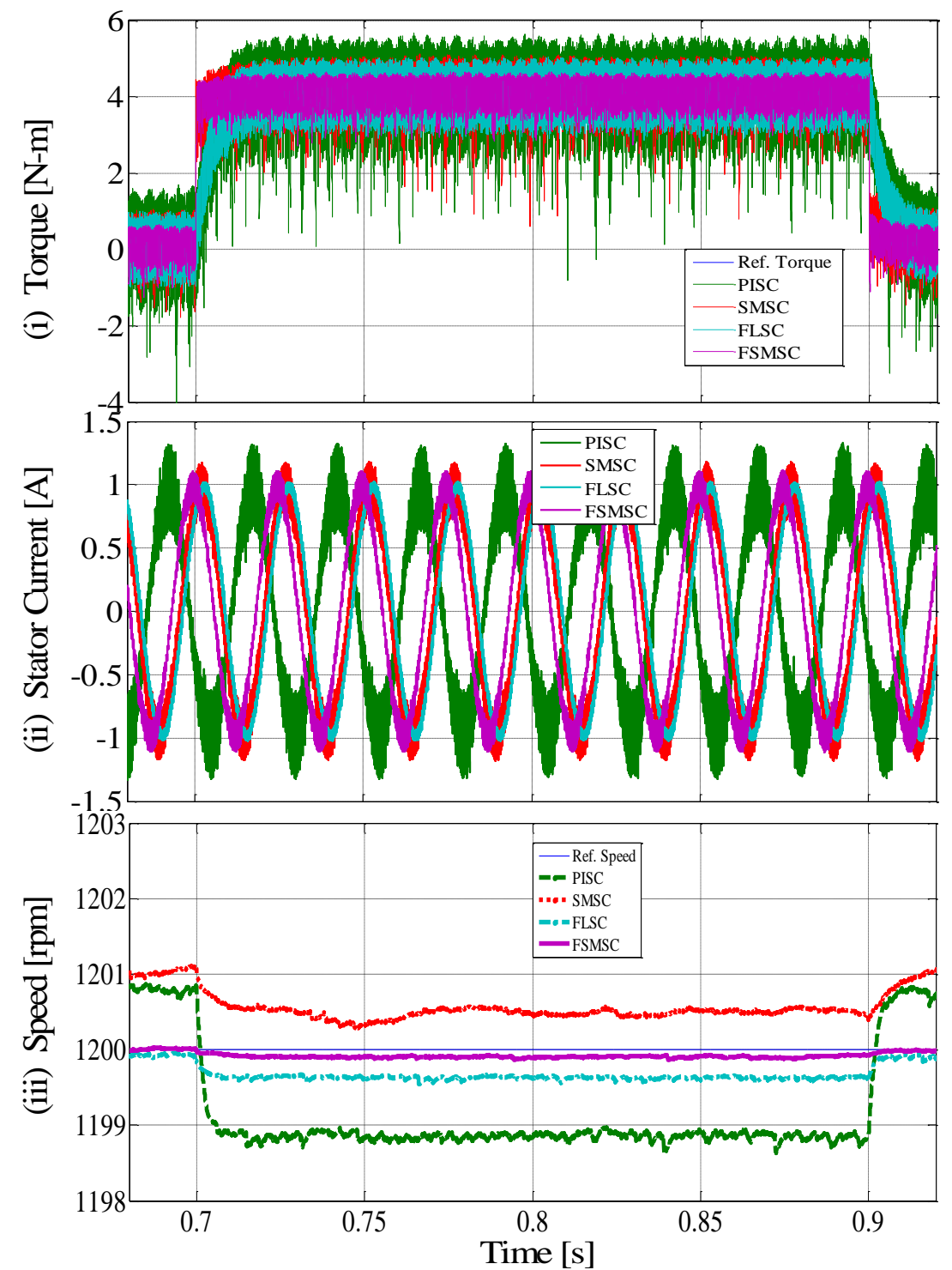

(b) 
Fuzzy Logic and Sliding-Mode Speed Control Based Direct Torque
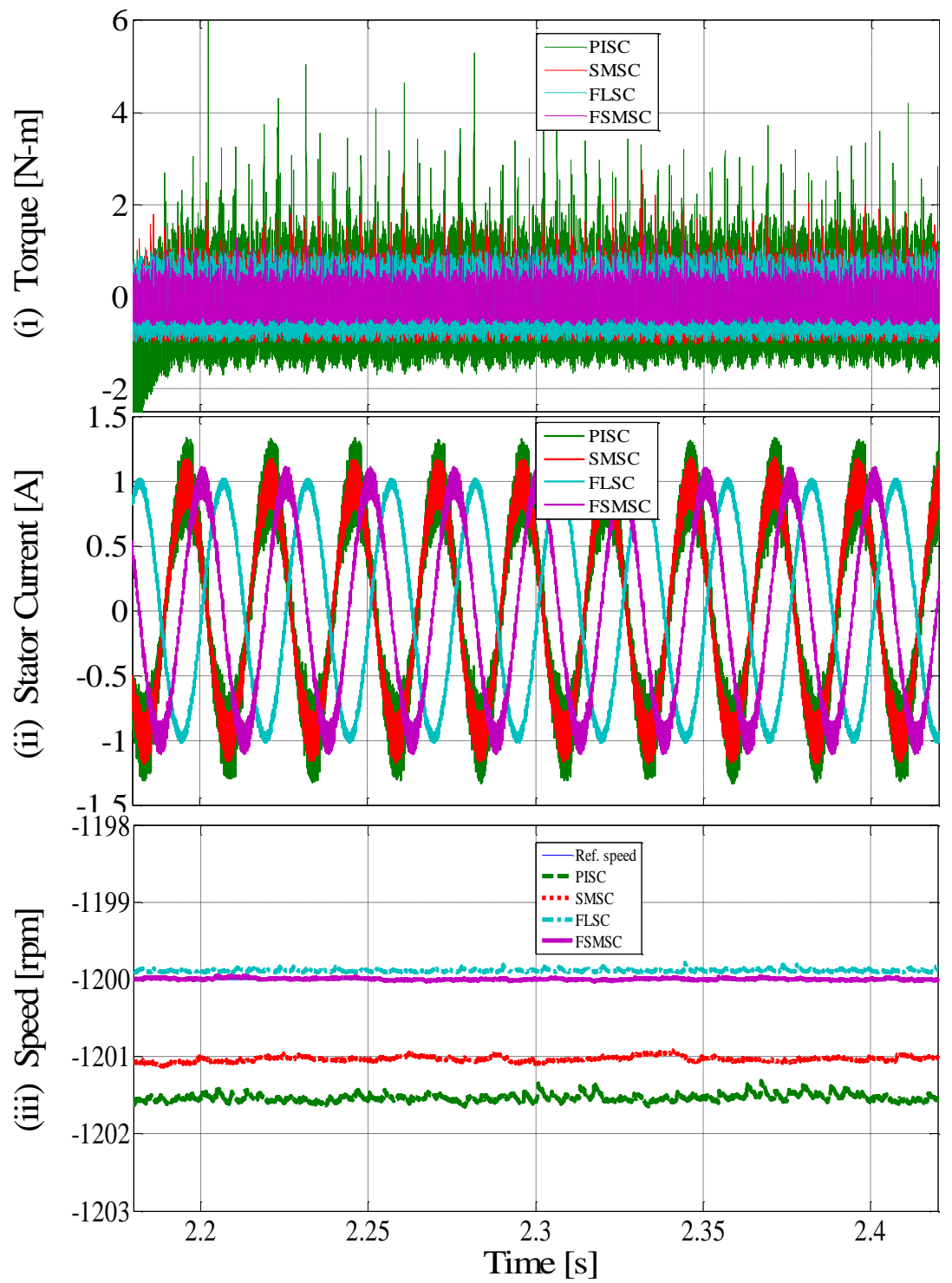

(c) 


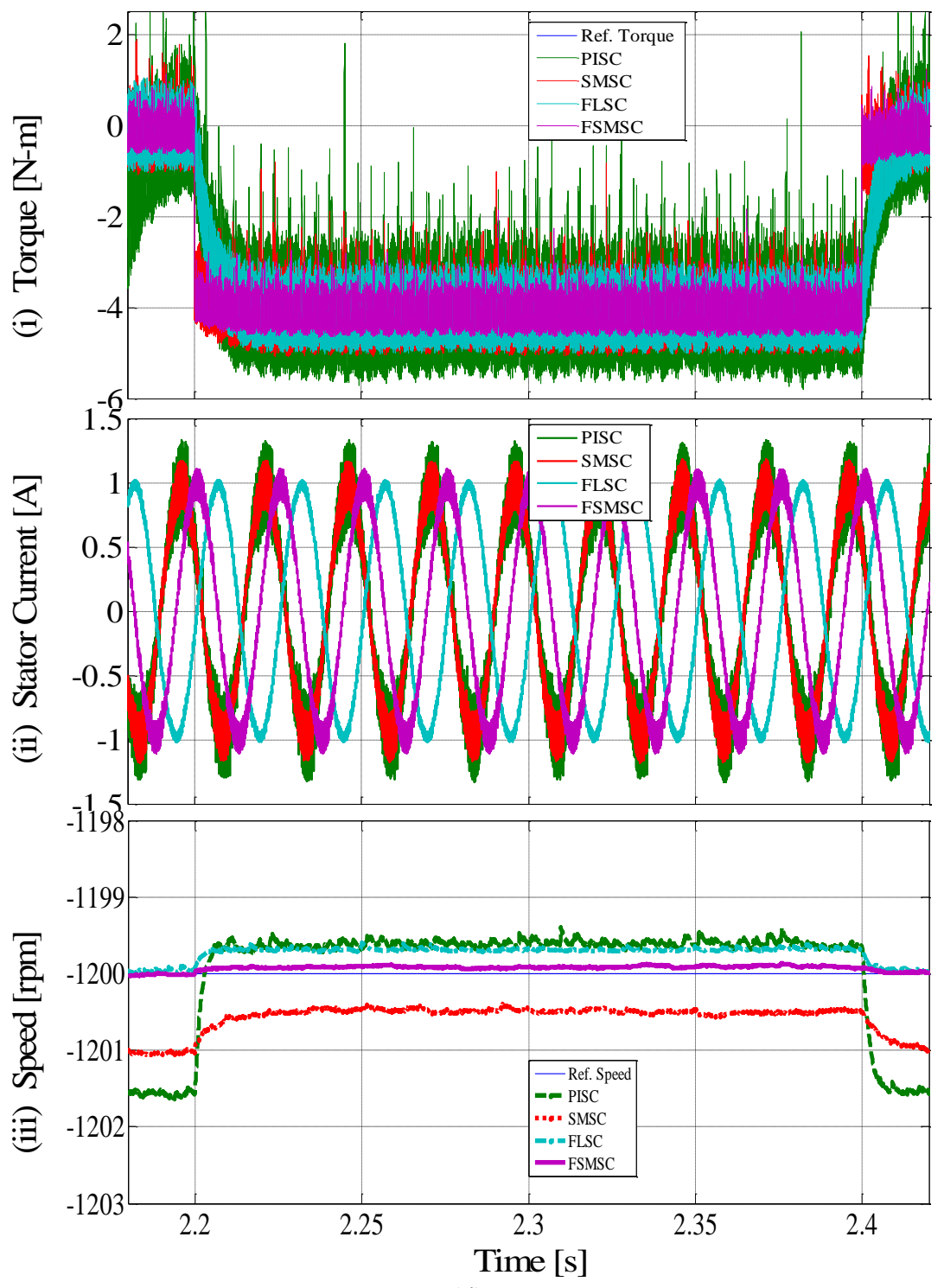

(d)

Figure. 8 Simulation responses of DTC IMD under $1200 \mathrm{rpm}$ operating conditions are:

(a) Forward motoring mode with No-load torque condition are:

(i). Torque, (ii). Stator Current and (iii). Speed.

(b) Forward motoring mode with Load torque of $4 \mathrm{~N}-\mathrm{m}$ condition are:

(i). Torque, (ii). Stator Current and (iii). Speed.

(c) Reverse motoring mode with No-load torque condition are:

(i). Torque, (ii). Stator Current and (iii). Speed.

(d) Reverse motoring mode with Load torque of $4 \mathrm{~N}-\mathrm{m}$ condition are:

(i). Torque, (ii). Stator Current and (iii). Speed. 

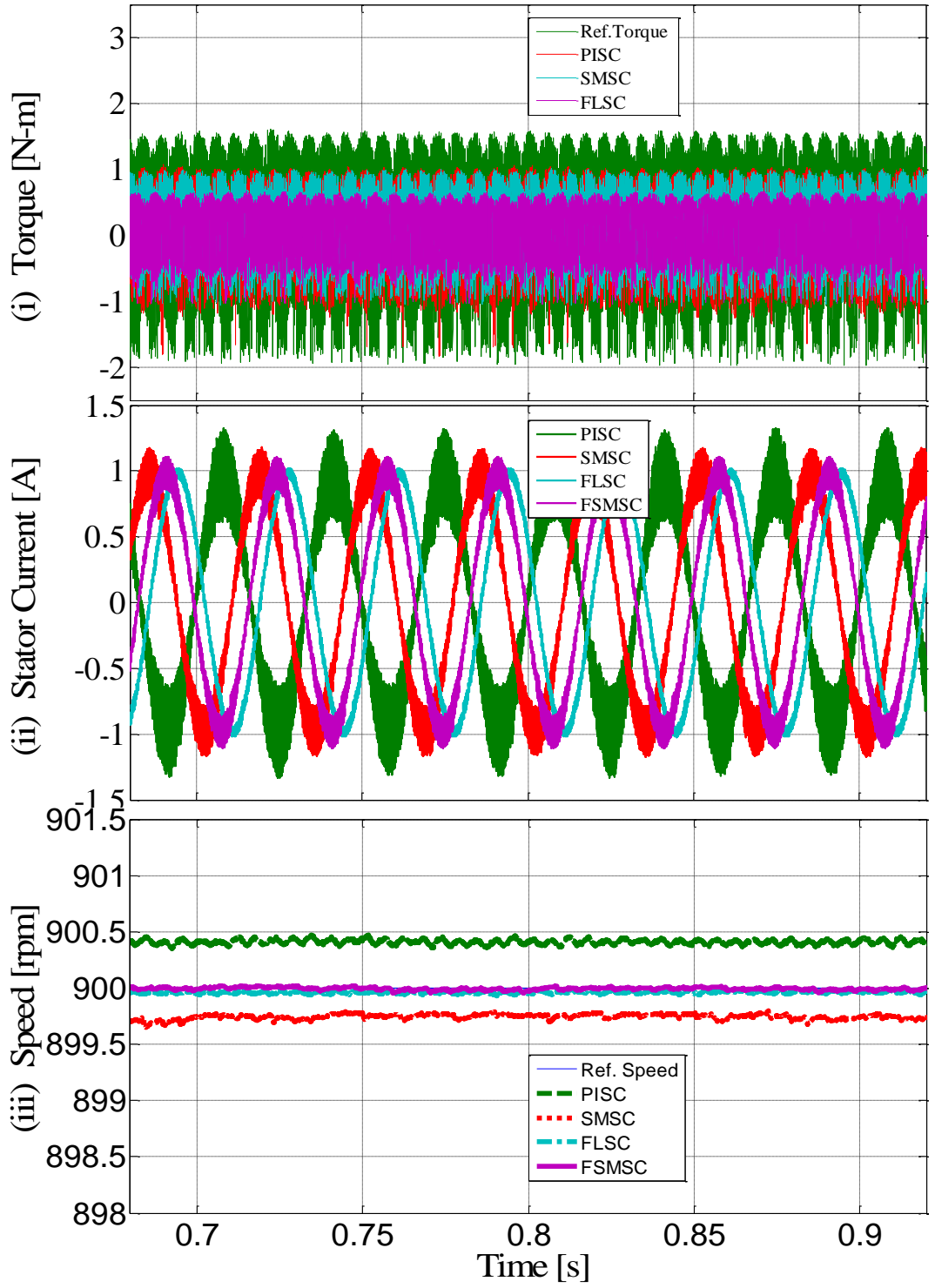

(a) 
Tejavathu Ramesh, et al.
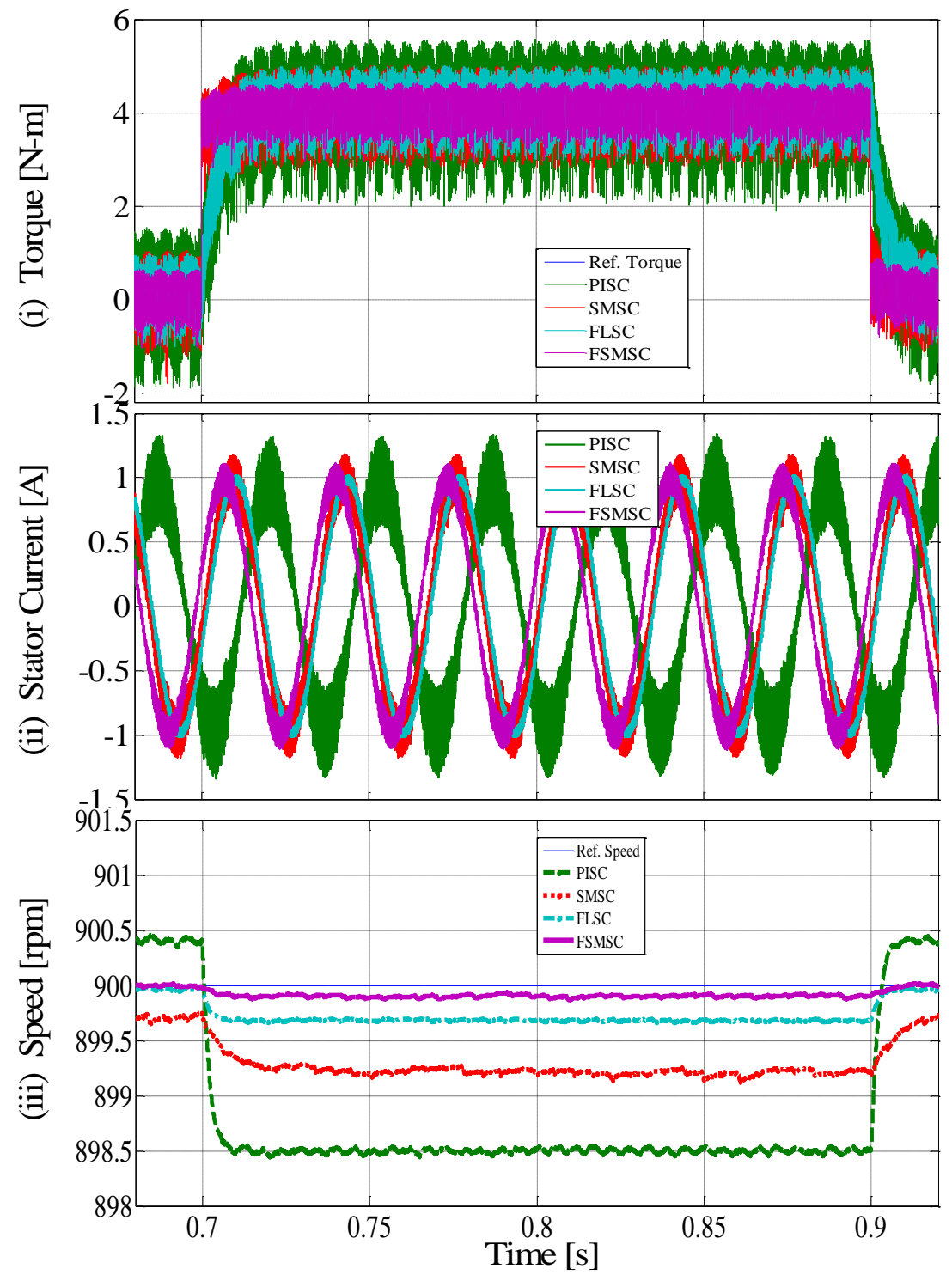

(b) 


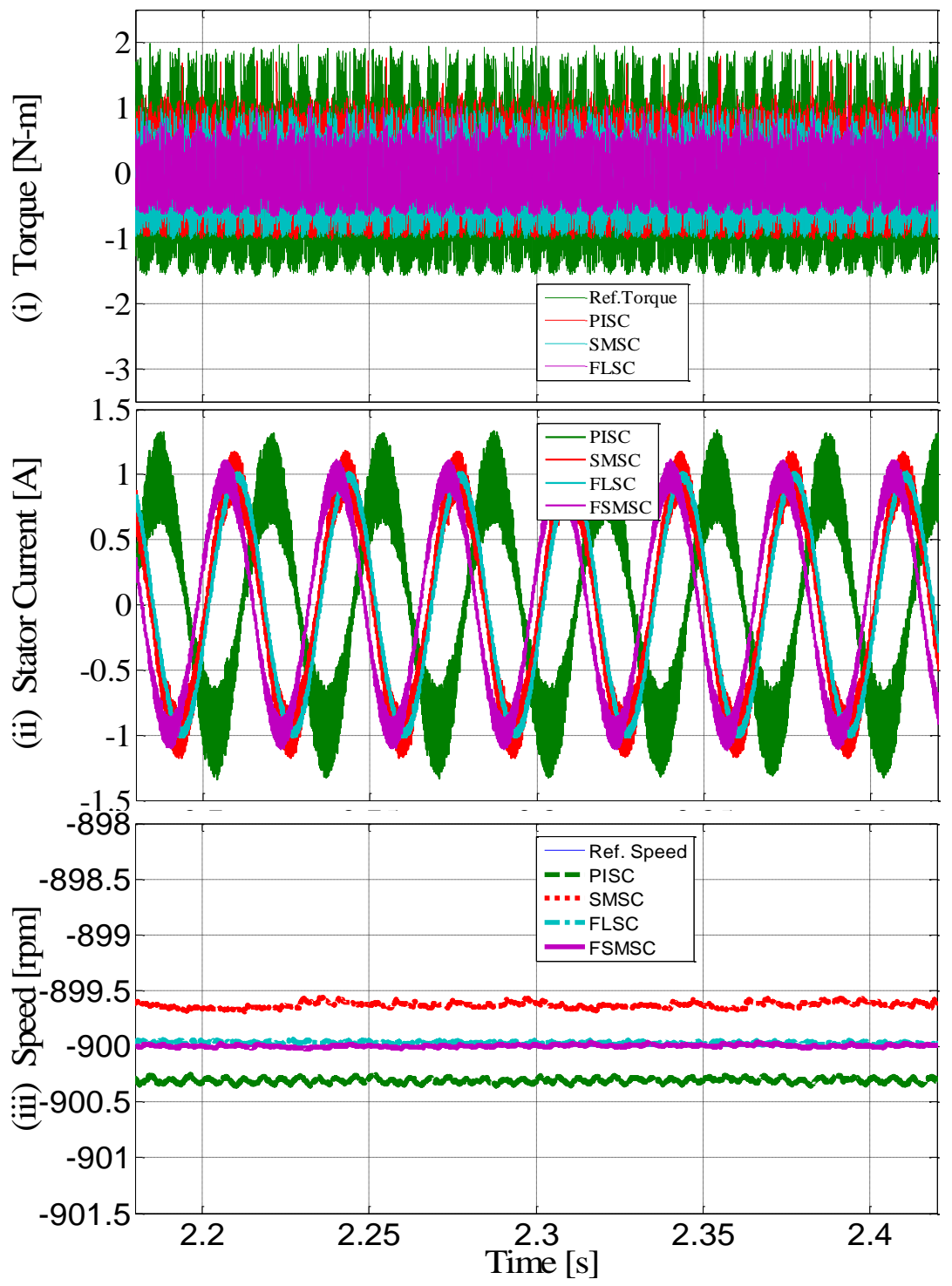

(c) 

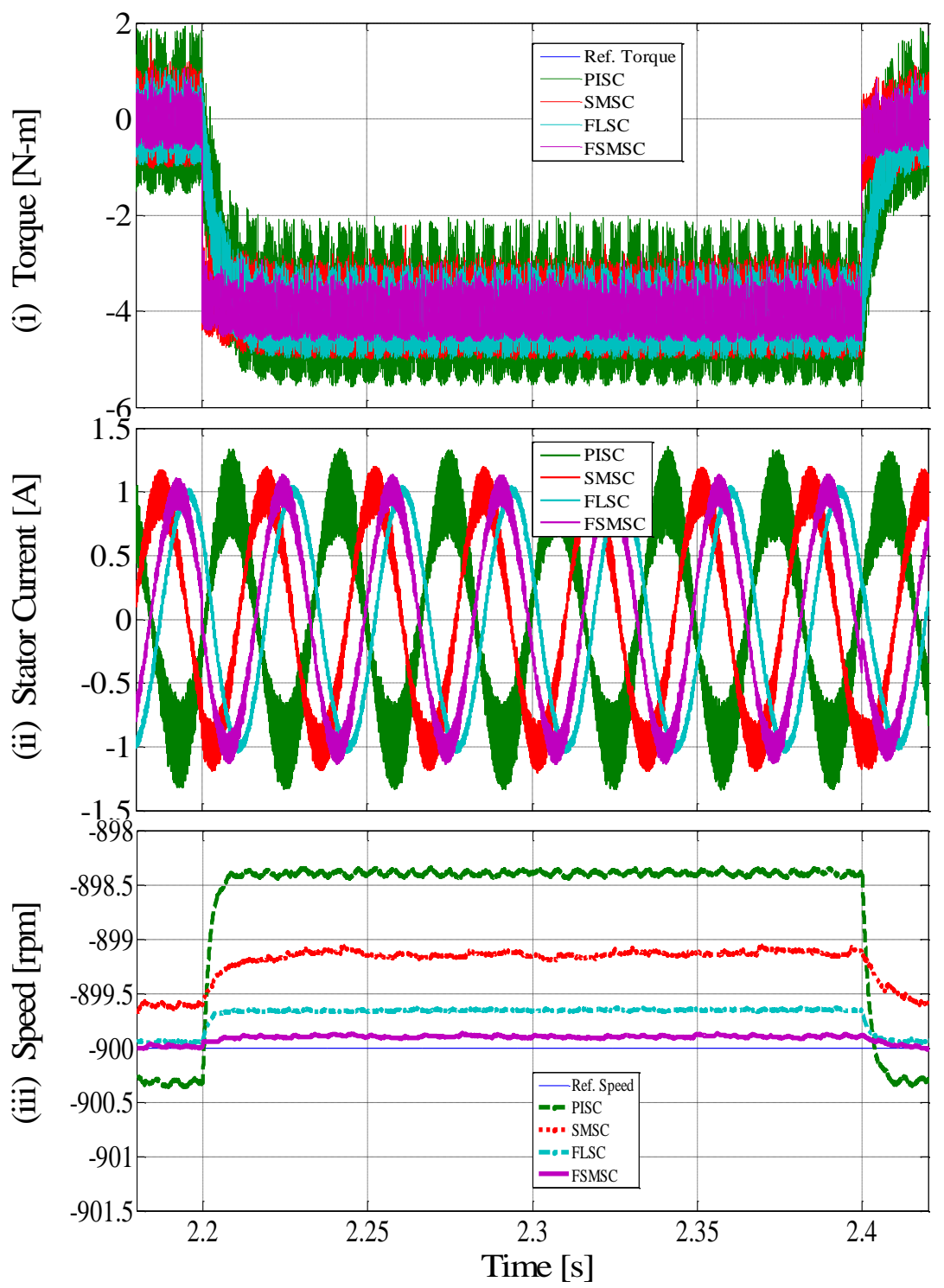

(d)

Figure 9. Simulation responses of DTC IMD under $900 \mathrm{rpm}$ operating conditions.

The performance of IMD is tested under $1200 \mathrm{rpm}$ and $900 \mathrm{rpm}$ with a load torque of $4 \mathrm{~N}$ $\mathrm{m}$ is applied at a time interval of $0.7 \mathrm{sec}$ under forward motoring mode is shown in Figure 8 (b) and Figure 9 (b), respectively. When a load is applied, the motor speed drops to 1200.81 to $1198.71 \mathrm{rpm}$ using PISC, and a slight drop from $1200 \mathrm{rpm}$ to $1199.73 \mathrm{rpm}$ using FSMSC.

The performance of IMD is tested by applying a speed reversal from $+1200 \mathrm{rpm}$ to -1200 rpm and $+900 \mathrm{rpm}$ to $-900 \mathrm{rpm}$ under no-load condition is shown in Figure 8 (c) and Figure 9 (c), respectively. The reversal motoring is applied at a time interval of $1 \mathrm{sec}$. The response of motor speed reaches its reference speed faster and also the ripple contents are less in SMSC and FMSC compared to PISC.

Then the performance of IMD is tested under $-1200 \mathrm{rpm}$ and $-900 \mathrm{rpm}$ with a load torque of - $4 \mathrm{~N}-\mathrm{m}$ is applied at a time interval of $2.2 \mathrm{sec}$ under reversal motoring is shown in Figure 8 (d) 
and Figure (d), respectively. The motor speed drops from -1201.54 to -1199.50 with a steady state error of $0.01167 \%$ using PISC and a slight drop in speed response from $-1200 \mathrm{rpm}$ to $1199.73 \mathrm{rpm}$ with a steady state error $0.0040 \%$ using FSMSC.

The performance of IMD is tested by applying sudden change in motor speed from $600 \mathrm{rpm}$ to $900 \mathrm{rpm}$ at $0.7 \mathrm{sec}$ and again speed changes from $900 \mathrm{rpm}$ to $1200 \mathrm{rpm}$ is applied at $1.2 \mathrm{sec}$ is shown in Figure 10 (e). The settling time of motor speed response is less in SM and FLSC compared to PISC.

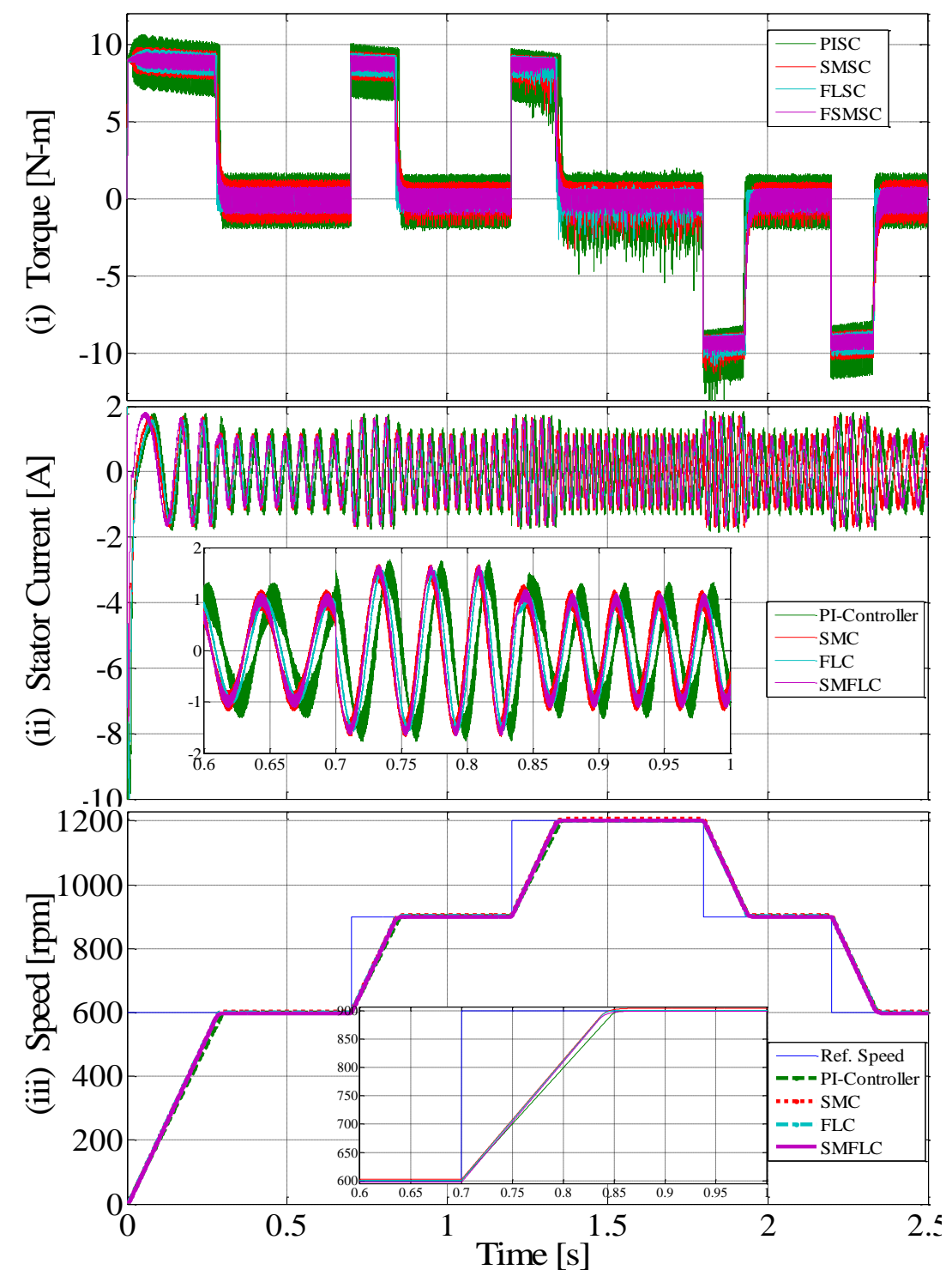

(e) 
Tejavathu Ramesh, et al.

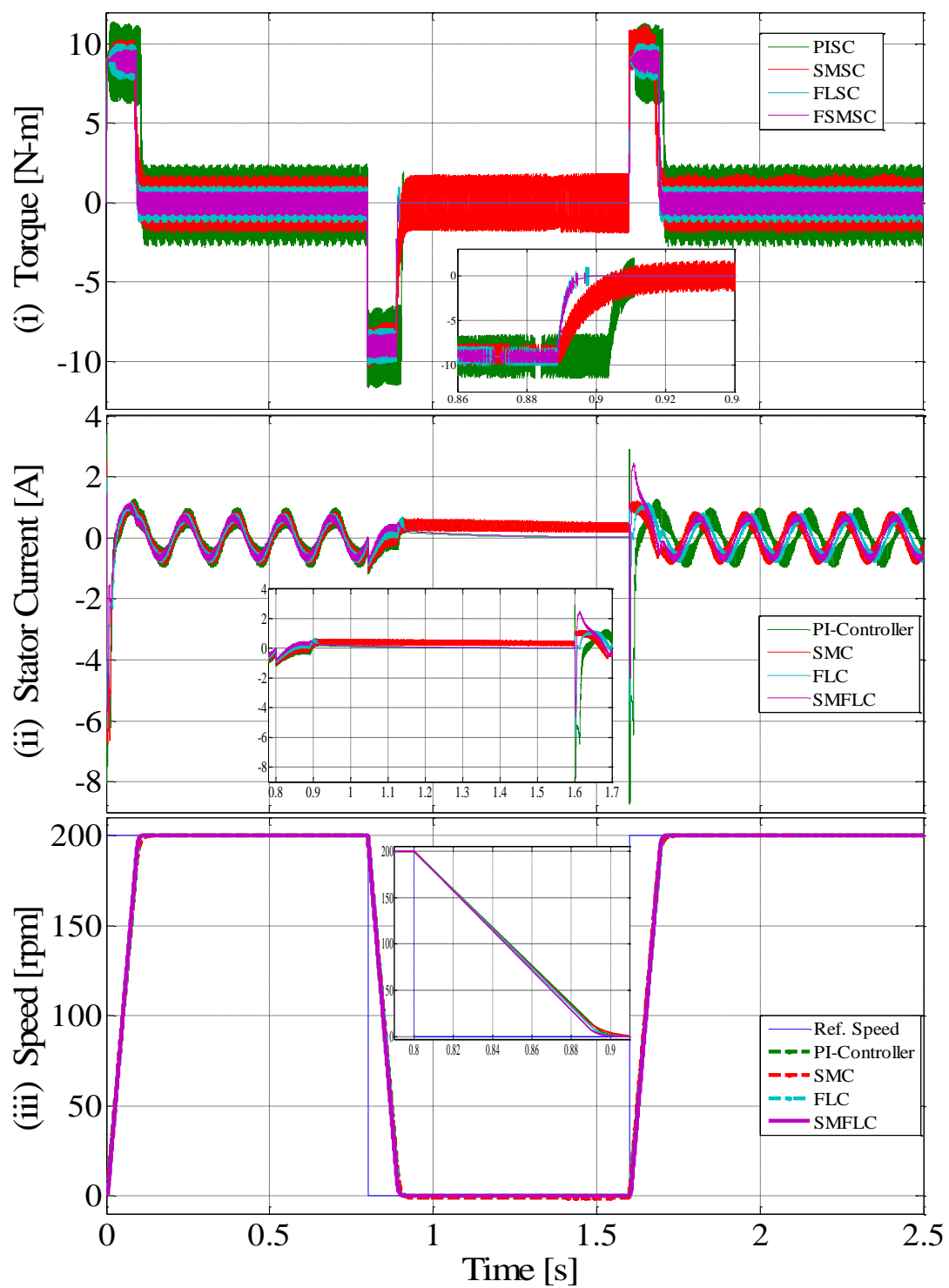

(f) 

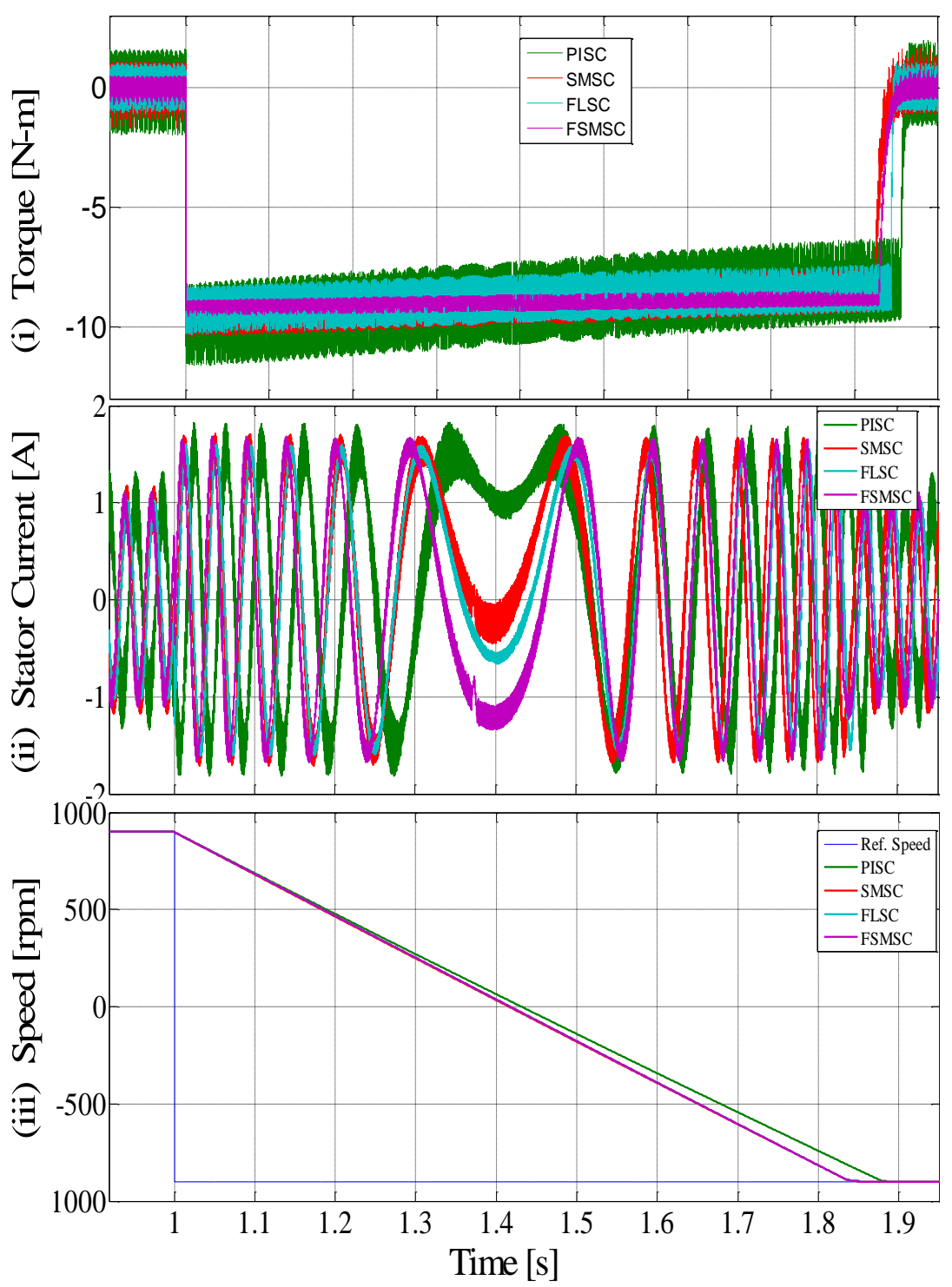

(g)

Figure 10. Simulation responses of DTC IMD are:

(e) Sudden Change in Speed responses are: (i). Torque, (ii). Stator Current and (iii). Speed

(f) Sudden Change in Speed from $200 \mathrm{rpm}$ to $0 \mathrm{rpm}$ responses are:

(i). Torque, (ii). Stator Current and (iii). Speed

(g) Motor speed response from $+900 \mathrm{rpm}$ to $-900 \mathrm{rpm}$ are: (i). Torque,

(ii). Stator Current and (iii). Speed

The performance of IMD when a sudden zero speed from $200 \mathrm{rpm}$ to $0 \mathrm{rpm}$ is applied at a time interval of $0.8 \mathrm{sec}$ and it is removed at $1.6 \mathrm{sec}$ is shown in Figure 10(f). There are some ripple contents in torque and stator current response with the SMSC approach under sudden zero speed condition compared to FLSC. The performance of IMD is tested under from +900 rpm to $-900 \mathrm{rpm}$ is shown in Figure $10(\mathrm{~g})$. The detailed comparison between the PISC, SMSC, FLSC and FSMSC schemes under $1200 \mathrm{rpm}$ is shown in Table 3 and under $900 \mathrm{rpm}$ is shown in Table 4. 
Table 3. Ripple contents of stator current, Torque, and motor speed Drops under 1200 RPM

\begin{tabular}{|c|c|c|c|c|}
\hline $\begin{array}{l}\text { Type of } \\
\text { control }\end{array}$ & $\begin{array}{l}\text { Torque } \\
\text { Ripples }\end{array}$ & $\begin{array}{l}\text { Current } \\
\text { Ripples }\end{array}$ & $\begin{array}{c}\text { Speed Drops } \\
\text { under Load and } \\
\text { steady state error } \\
\%\end{array}$ & $\begin{array}{c}\text { Speed Settling } \\
\text { Time }\end{array}$ \\
\hline PISC & 5.8 N.m & $0.74 \mathrm{~A}$ & $\begin{array}{c}2.05 \mathrm{rpm} \mathrm{\&} \\
0.01167 \%\end{array}$ & $0.614 \mathrm{sec}$ \\
\hline SMSC & 3.92 N.m & $0.42 \mathrm{~A}$ & $\begin{array}{c}0.61 \mathrm{rpm} \& \\
0.01025 \%\end{array}$ & $0.585 \mathrm{sec}$ \\
\hline FLSC & 2.12 N.m & $0.095 \mathrm{~A}$ & $0.35 \mathrm{rpm} \&$ & $0.582 \mathrm{sec}$ \\
\hline FSMSC & 1.96 N.m & $0.094 \mathrm{~A}$ & $\begin{array}{c}0.00428 \% \\
0.27 \mathrm{rpm} \mathrm{\&} \\
0.0040 \%\end{array}$ & $0.573 \mathrm{sec}$ \\
\hline
\end{tabular}

Table 4. Ripple contents of stator current, Torque, and motor speed Drops under 900 RPM

\begin{tabular}{|c|c|c|c|c|}
\hline $\begin{array}{l}\text { Type of } \\
\text { control }\end{array}$ & $\begin{array}{l}\text { Torque } \\
\text { Ripples }\end{array}$ & $\begin{array}{l}\text { Current } \\
\text { Ripples }\end{array}$ & $\begin{array}{l}\text { Speed Drops under } \\
\text { Load and steady } \\
\text { state error \% }\end{array}$ & $\begin{array}{c}\text { Speed Settling } \\
\text { Time }\end{array}$ \\
\hline PISC & 4.6 N.m & $0.705 \mathrm{~A}$ & $\begin{array}{l}1.9 \mathrm{rpm} \mathrm{\&} \\
0.01222 \%\end{array}$ & $0.459 \mathrm{sec}$ \\
\hline SMSC & 2.41 N.m & $0.392 \mathrm{~A}$ & $\begin{array}{c}0.56 \mathrm{rpm} \& \\
0.01022 \%\end{array}$ & $0.453 \mathrm{sec}$ \\
\hline FLSC & 2.1 N.m & $0.08 \mathrm{~A}$ & $0.31 \mathrm{rpm} \&$ & $0.441 \mathrm{sec}$ \\
\hline FSMSC & 1.82 N.m & 0.078 & $\begin{array}{c}0.00422 \% \\
0.255 \mathrm{rpm} \& \\
0.0039 \%\end{array}$ & $0.437 \mathrm{sec}$ \\
\hline
\end{tabular}

\section{Conclusion}

In this paper, direct torque and flux control of induction motor drive using four different speed controller techniques have been tested in MATLAB/Simulink in order to obtain the high performance drive. The PISC works well under normal operation but less capable of sudden change in speed and load torque disturbance rejection due to the fixed gain values. Adaptive speed control structures shows good disturbance rejection capability and robustness against to parameter uncertainties in IMD compared to fixed gain controller. SMSC scheme works well and give high performance drive but robustness of the system becomes highly dependent on the boundary layer thickness. FLSC having capability of disturbance rejection and robustness to parameter variations, but still needs some modifications to improve the performance of IMD. FSMSC scheme has a fast load torque disturbance rejection capability and robustness to parameter variations but it needs some modifications to minimise the chattering phenomenon in the steady state condition. A detailed comparison between the four speed control techniques has been carried out in DTFC IMD.

\section{Reference}

[1] Buja G. S., Kazmierkowski M. P., 'DTC of pwm inverter-fed AC motors - A Survey', IEEE Trans. on Ind. Elec., 2004, Vol. 54, (5), pp. 744 - 757.

[2] Blaschke F., 'The principle of field-orientation as applied to the transvector closed-loop control system for rotating-field machines', Siemens Rev., 1988, Vol. 34, pp. 135-147.

[3] Takahashi I., Noguchi T., 'A new quick response and high efficiency control strategy of an induction motor', IEEE Trans. Ind. Appl., 1986,Vol. 22, (5), pp. 820-827.

[4] Lin F., Shieh H., Shyu K., Huang P., 'Online gain tuning IP controller using realcoded genetic algorithm', Journal of Electric Power Syst. Res., 2004, Vol.72, pp.157-169. 
[5] Gadoue S. M., Giaouris D., Finch J.W., 'Tuning of PI speed controller in DTC of induction motor based on genetic algorithms and fuzzy logic schemes', Proc. of the 5th Int. Conf. on Tech. and Auto., 2005, pp. 85-90.

[6] Lascu C., Boledea I., Blaabjerg F., 'Direct torque control of sensorless induction motor drives: A sliding-mode approach', IEEE Trans. on Industry Appl., 2004, Vol. 40, (2), pp. 582-590.

[7] Uddin M. N., Radwan T. S., Rahman M., 'Performance of fuzzy-logic-based indirect vector control for induction motor drive', IEEE Trans. Ind. Appl., 2002, Vol. 38, (5), pp. 1219-1225.

[8] Barrero F., Gonzalez A., Torralba A., Galvan E., Franquelo L.G., 'Speed control of induction motors using a novel fuzzy sliding mode structure', IEEE Trans. Fuzzy Syst., 2002, Vol. 10, pp. 375-383.

[9] Oh W., Kim Y., Kim C., Kwon T., Kim H., 'Speed control of induction motor using genetic algorithm based fuzzy controller', Proc. of the IECON'99, 1999, Vol. 2, pp. 625629.

[10] Luo Y., Chen W., 'Sensorless stator field orientation controlled induction motor drive with a fuzzy speed controller', Comp. and Mathematics with App., 2012, Vol. 64, pp. $1206-1216$.

[11] Foo G., Rahman M.F., 'Direct torque and flux control of an IPM synchronous motor drive using a backstepping approach', IET Electr. Power Appl., 2009, Vol. 3, (5), pp. 413-421.

[12] Barambones O., Garrido A.J., Maseda F.J., 'Integral sliding mode controller for induction motor based on FOC theory', IET Control Theory Appl., 2007, 1, (3), pp. 786-794.

[13] Zhang Y., Zhu J., Xu W., Hu J., Dorrell D. G., Zhaoy Z., 'Speed Sensorless Stator Flux Oriented Control of Three-Level Inverter-Fed Induction Motor Drive Based on Fuzzy Logic and Sliding Mode Control', Proc. In $36^{\text {th }}$ Annual Conf. on IEEE Ind. Elect. Society (IECON-2010), 2010, pp. 2932 - 2937.

[14] Chen C., 'Sliding mode controller design of induction motor based on space-vector pulsewidth modulation method', Int. Journal of Innovative Comp., Information and Control, 2009, Vol. 5, (10).

[15] Mohanty K. B., 'Sensorless sliding mode control of induction motor drives', Proc. of IEEE TENCON, 2008, pp.1-6.

[16] Oliveira J.B., Araujo A.D., Dias S.M., 'Controlling the speed of a three-phase induction motor using a simplified indirect adaptive sliding mode scheme', Control Engineering Practice, 2010, Vol. 18, pp. 577-584.

[17] Gadoue S. M., Giaouris D., Finch J. W., 'MRAS sensorless vector control of an induction motor using new sliding-mode and fuzzy-logic adaptation mechanisms', IEEE Trans. Energy Conv., 2010, Vol. 25, pp. 394-402.

[18] Lai Y., Lin J., 'New hybrid fuzzy controller for direct torque control induction motor drives', IEEE Trans. Power Electron., 2003, Vol. 18, pp. 1211-1219.

[19] Bose B. K., 'Modern Power Electronics and AC Drives', Prentice Hall Indic, 2006.

[20] Slotine J. J. E, W. Li, 'Applied Nonliner Control', Prentice hall, 1991.

[21] Mikkili S., Panda A.K., 'PI and Fuzzy Logic Controller based 3-phase 4-wire Shunt active filter for mitigation of Current harmonics with Id-Iq Control Strategy', Journal of power Electronics (JPE), 2011, Vol. 11, (6).

[22] Hazzab A., Bousserhane I.K., Kamli M., Design of fuzzy sliding mode controller by genetic algorithms for induction machine speed control, Int. J. Emerging Electric Power Syst., 2004, (1), pp. 1016-1027. 


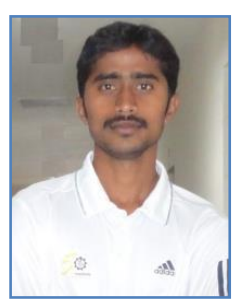

Tejavathu Ramesh was born in Khammam, Andhra Pradesh, India on th

9 April 1987. He received B.Tech degree in Department of Electrical and Electronics Engineering from G.R.I.E.T affiliated to JNTU Hyderabad, Andhra Pradesh, India in May 2009 and Masters (M.Tech) in Department of Electrical Engineering from N.I.T Rourkela, Orissa, India in May 2011. $\mathrm{He}$ is currently working as an Assistant Professor in Department of Electrical Engineering at National Institute of Technology Kurukshetra, and pursuing Ph.D in Department of Electrical Engineering at National Institute of Technology Rourkela, Orissa, India. His main area of research includes Power electronics and drives, Applications of Soft Computing Techniques, and Artificial Intelligent.

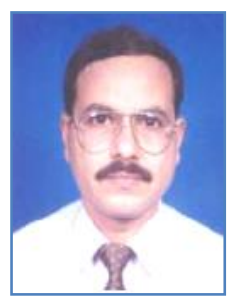

Anup Kumar Panda received the B.Tech in Electrical Engineering from Sambalpur University, India in 1987. He received the M.Tech in Power Electronics and Drives from Indian Institute of Technology, Kharagpur, India in 1993 and Ph.D. in 2001 from Utkal University. Join as a faculty in IGIT, Sarang in 1990. Served there for eleven years and then join National Institute of Technology, Rourkela in January 2001 as an assistant professor and currently continuing as a Professor in the Department of Electrical Engineering. He has published over hundred articles in journals and conferences. He has completed two MHRD projects and one NaMPET project. Guided six Ph.D. scholars and currently guiding six scholars in the area of Power Electronics \& Drives. His research interest include analysis and design of high frequency power conversion circuits, power factor correction circuits, power quality improvement in power system and electric drives, Applications of Soft Computing Techniques.

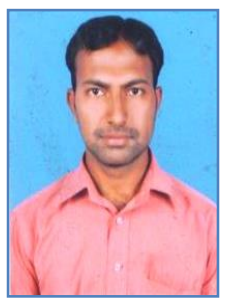

S. Shiva Kumar received the B.Tech in Electrical Engineering from Gokaraju Rangaraju Institute of Engineering and Technology (GRIET) affiliated to Jawaharlal Nehru Technological University (JNTUK), India in 2009. He received the M.Tech in Power Electronics and Drives from Gokaraju Rangaraju Institute of Engineering and Technology affiliated to Jawaharlal Nehru Technological University (JNTUK), India in 2011 and Pursuing Ph.D. National Institute of Technology Rourkela (NITR). Worked as a faculty in GRIET Hyderabad in 2010 for about a year. His research interest includes analysis and design of high frequency power conversion circuits, power factor correction circuits, SMPS, electric drives, hybrid electric vehicles. 